\title{
Determination of Femtogram-Level Plutonium Isotopes in Environmental and Forensic Samples with High-Level Uranium Using Chemical Separation and ICP-MS/MS Measurement
}

Hou, Xiaolin; Zhang, Weichao; Wang, Yanyun

Published in:

Analytical Chemistry

Link to article, DOI:

10.1021/acs.analchem.9b01347

Publication date:

2019

Document Version

Peer reviewed version

Link back to DTU Orbit

Citation (APA):

Hou, X., Zhang, W., \& Wang, Y. (2019). Determination of Femtogram-Level Plutonium Isotopes in Environmental and Forensic Samples with High-Level Uranium Using Chemical Separation and ICP-MS/MS Measurement. Analytical Chemistry, 91(18), 11553-11561. https://doi.org/10.1021/acs.analchem.9b01347

\section{General rights}

Copyright and moral rights for the publications made accessible in the public portal are retained by the authors and/or other copyright owners and it is a condition of accessing publications that users recognise and abide by the legal requirements associated with these rights.

- Users may download and print one copy of any publication from the public portal for the purpose of private study or research.

- You may not further distribute the material or use it for any profit-making activity or commercial gain

- You may freely distribute the URL identifying the publication in the public portal 
Article

Subscriber access provided by DTU Library

\author{
Determination of femtogram level plutonium isotopes in \\ environmental and forensic samples with high-level uranium \\ using chemical separation and ICP-MS/MS measurement \\ Xiaolin Hou, Weichao Zhang, and Yanyun Wang
}

Anal. Chem., Just Accepted Manuscript • DOI: 10.1021/acs.analchem.9b01347 • Publication Date (Web): 16 Aug 2019

Downloaded from pubs.acs.org on August 19, 2019

\title{
Just Accepted
}

"Just Accepted" manuscripts have been peer-reviewed and accepted for publication. They are posted online prior to technical editing, formatting for publication and author proofing. The American Chemical Society provides "Just Accepted" as a service to the research community to expedite the dissemination of scientific material as soon as possible after acceptance. "Just Accepted" manuscripts appear in full in PDF format accompanied by an HTML abstract. "Just Accepted" manuscripts have been fully peer reviewed, but should not be considered the official version of record. They are citable by the Digital Object Identifier (DOIB). "Just Accepted" is an optional service offered to authors. Therefore, the "Just Accepted" Web site may not include all articles that will be published in the journal. After a manuscript is technically edited and formatted, it will be removed from the "Just Accepted" Web site and published as an ASAP article. Note that technical editing may introduce minor changes to the manuscript text and/or graphics which could affect content, and all legal disclaimers and ethical guidelines that apply to the journal pertain. ACS cannot be held responsible for errors or consequences arising from the use of information contained in these "Just Accepted" manuscripts. 


\title{
Determination of femtogram level plutonium isotopes in environmental and forensic samples with high-level uranium using chemical separation and ICP- MS/MS measurement
}

\author{
Xiaolin $\mathrm{Hou}^{1,2,3,5^{*}, \text { Weichao Zhang }}{ }^{1,4}$, Yanyun Wang ${ }^{1,4}$ \\ 1 State Key Laboratory of Loess and Quaternary Geology, Shaanxi Key Laboratory of Accelerator \\ Mass Spectrometry Technology and Application, Xi'an AMS Center, Institute of Earth \\ Environment, Chinese Academy of Sciences, Xi'an 710061, China \\ 2 Center for Nuclear Technologies, Technical University of Denmark, DTU Nutech, Roskilde DK- \\ 4000, Denmark \\ 3 CAS Center of Excellence in Quaternary Science and Global Change, Xi'an 710061, China \\ 4 University of Chinese Academy of Sciences, Beijing 100049, China \\ 5 Open Studio for Oceanic-Continental Climate and Environment Changes, Pilot National \\ Laboratory for Marine Science and Technology (Qingdao), Qingdao 266061, China
}

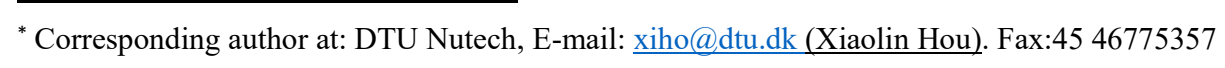




\begin{abstract}
ICP-MS is becoming a competitive technique for the measurement of plutonium isotopes. However, the abundance sensitivity (tailing of ${ }^{238} \mathrm{U}$ to $\mathrm{m} / \mathrm{z}=239$ and 240 ), isobaric and polyatomic ions interferences (e.g. ${ }^{238} \mathrm{U}^{1} \mathrm{H}^{+}$) are the most critical challenges for determination of low-level plutonium in high uranium samples. This work presents a new method to solve this problem using ICP- MS with two tandem quadrupole separators and dynamic collision/reaction cell combined with chemical separation. The interference of uranium hydrides $\left({ }^{238} \mathrm{U}^{1} \mathrm{H}^{+}\right.$and ${ }^{238} \mathrm{U}^{1} \mathrm{H}_{2}^{+}$) was effectively eliminated using $\mathrm{CO}_{2}$ as reaction gas by converting hydrides to oxides of uranium ions $\left(\mathrm{UO}^{+} / \mathrm{UO}_{2}{ }^{+}\right)$, but still keep the intensity of $\mathrm{Pu}^{+}$signal. The tailing interference of ${ }^{238} \mathrm{U}^{+}$(abundance sensitivity) was intensively eliminated by significantly suppressing the ${ }^{238} \mathrm{U}^{+}$ signal using $\mathrm{CO}_{2}$ as reaction gas and using two tandem quadrupole mass separators in the ICPMS/MS. With these approaches, the overall interference of uranium was reduced to $<1 \times 10^{-8}$, which is 3 orders of magnitude better than the conventional ICP-MS. Combined with chemical separation with a decontamination factor of $10^{5}$ for uranium, an overall factor of $10^{12}$ for elimination of uranium interference was achieved. The developed method was demonstrated to enable accurate determination of $<10^{-15} \mathrm{~g} / \mathrm{g}$ level plutonium isotopes in environmental samples even in uranium debris sample with a $\mathrm{U} / \mathrm{Pu}$ atomic ratio up to $10^{12}$. The developed method was validated by the analysis of spiked solution and certified reference materials of soil.
\end{abstract}

Keyword: ICP-MS/MS, Collision/Reaction cell, reaction gas, $\mathrm{CO}_{2}-\mathrm{He}$, Plutonium isotopes, Uranium interference 


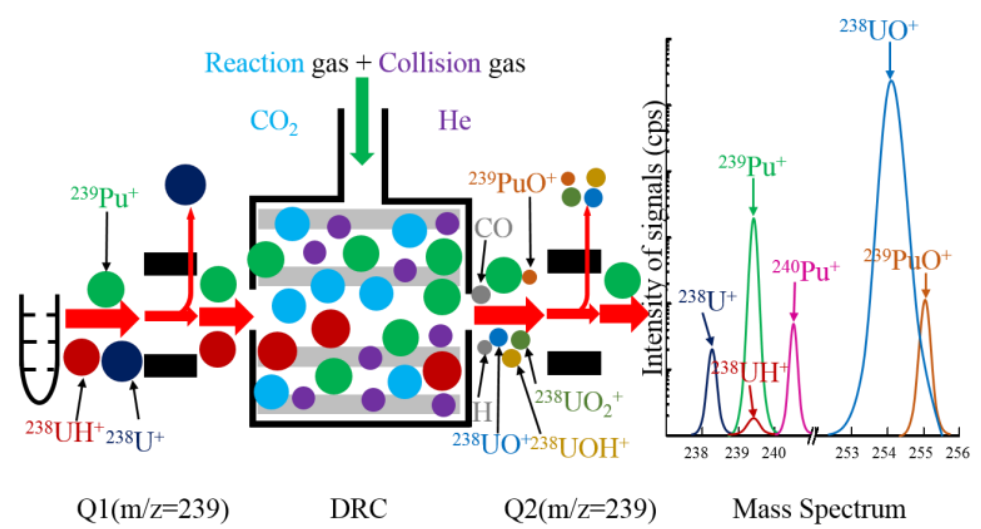

\section{INTRODUCTION}

Plutonium is one of the most important transuranic elements in the environment due to its widely utilization and production in nuclear weapons and nuclear power reactors. Among plutonium isotopes, ${ }^{239} \mathrm{Pu}\left(\mathrm{t}_{1 / 2}=2.41 \times 10^{4} \mathrm{y}\right)$ and ${ }^{240} \mathrm{Pu}\left(\mathrm{t}_{1 / 2}=6.56 \times 10^{3} \mathrm{y}\right)$ are long-lived alphaemitting radionuclides and the most important ones in the nuclear fuel and environment due to their high production and releases. Plutonium is a critical hazardous environmental pollutant due to its highly radiological toxicities and long-term persistent in the environment. Plutonium in the environment mainly originates from atmospheric nuclear weapons tests, nuclear fuel reprocessing plants and nuclear accidents ${ }^{1}$. The atmospheric nuclear weapons tests in 1945-1980 had released $6.5 \times 10^{15} \mathrm{~Bq}$ of ${ }^{239} \mathrm{Pu}$ and $4.4 \times 10^{15} \mathrm{~Bq}$ of ${ }^{240} \mathrm{Pu}$ into the environment, making it the major source of plutonium in the environment ${ }^{1,2}$. It is important to monitor it for evaluation of environmental impact of nuclear activities and possible radiological attack. The atomic ratios of ${ }^{240} \mathrm{Pu} /{ }^{239} \mathrm{Pu}$ vary with its sources depending on the production and release model, a ratio of 0.18 in the global fallout was observed all over the world ${ }^{3}$, while, much lower ratios of 0.02-0.07 in nuclear weapons ${ }^{4,5}$ and higher ratios of $0.23-0.47$ in the releases from the nuclear accidents in Chernobyl and 
Fukushima and reprocessing plants of nuclear spent fuel of power reactors ${ }^{6-8}$ were measured. The ${ }^{240} \mathrm{Pu} /{ }^{239} \mathrm{Pu}$ atomic ratio can therefore be used as a fingerprint to identify the source term of the plutonium and estimate the contribution of different nuclear activities to the environment ${ }^{9}$, as well as for nuclear forensic investigation ${ }^{10}$. For these purposes, an analytical method for accurate determination of low level ${ }^{239} \mathrm{Pu}$ and ${ }^{240} \mathrm{Pu}$ is necessary and very critical.

${ }^{239} \mathrm{Pu}$ and ${ }^{240} \mathrm{Pu}$ are conventionally measured by $\alpha$-spectrometry, but it is unable to provide ${ }^{240} \mathrm{Pu} /{ }^{239} \mathrm{Pu}$ atomic ratio, because alpha spectrometry could not distinguish the alpha rays of ${ }^{239} \mathrm{Pu}$ $(5.15 \mathrm{MeV})$ and ${ }^{240} \mathrm{Pu}(5.16 \mathrm{MeV}){ }^{11}$. Meanwhile, it cannot measure ultra-low level ${ }^{239} \mathrm{Pu}$ and ${ }^{240} \mathrm{Pu}$ of less than $0.1 \mathrm{mBq}$ (or $5 \times 10^{-14} \mathrm{~g}{ }^{239} \mathrm{Pu}+{ }^{240} \mathrm{Pu}$ ). With the rapid development of mass spectrometry, it has being become an attractive technique for determination of long-lived radionuclides including plutonium isotope in the past decades. Among them, AMS and TIMS have high sensitivity and low detection limit, but they are not easily accessible and high cost ${ }^{10-13}$. ICP-MS has become a widely used technique for the measurement of plutonium isotopes in environmental samples with a comparable or better sensitivity compared with alpha spectrometry, low cost and ability to measure ${ }^{240} \mathrm{Pu} /{ }^{239} \mathrm{Pu}$ atomic ratio ${ }^{2,9,11,14,15}$.

The concentrations of plutonium isotopes $\left({ }^{239,}{ }^{240} \mathrm{Pu}\right)$ in environmental samples are normally very low, to be $(0.04-400) \times 10^{-16} \mathrm{~g} / \mathrm{m}^{3}$ in the atmosphere ${ }^{16,17},(1-900) \times 10^{-15} \mathrm{~g} / \mathrm{g}$ in soil and sediment $9,18-21$, and $(0.5-22) \times 10^{-16} \mathrm{~g} / \mathrm{L}$ in seawater samples ${ }^{22,23}$. The accurate determination of trace amount of plutonium isotopes requires a high enrichment of plutonium from a large size of sample and separation from matrices and interfering substances, as well as a sensitive measurement method. The matrix elements (salt), peak tailing and hydrides of ${ }^{238} \mathrm{U}$ and the polyatomic ions ${ }^{2,24}$ are the major interference in the measurement of plutonium isotopes using ICP-MS. Among them, the interference of uranium including peak tailing and hydride ions of ${ }^{238} \mathrm{U}^{238} \mathrm{U}^{1} \mathrm{H}^{+}$and $\left.{ }^{238} \mathrm{U}^{1} \mathrm{H}_{2}{ }^{+}\right)$is 
the most critical one limiting the accurate measurement of ${ }^{239} \mathrm{Pu}$ and ${ }^{240} \mathrm{Pu}$. Co-precipitation, ion exchange chromatography and extraction chromatography are often applied for separation and purification of plutonium in environmental samples, especially for removal of uranium ${ }^{15}$. Multisteps separation, e.g. combination of ion exchange and extraction chromatography using different resins, such as TEVA+AG1- $\times 4{ }^{20}, \mathrm{UTEVA}+\mathrm{TRU}{ }^{25}$, TRU $+\mathrm{AG} 1-\times 4{ }^{26}$ and TEVA+UTEVA+DGA ${ }^{18}$ has been used, and a decontamination factors of $10^{5}-10^{7}$ for uranium have been achieved. However, this is still not sufficient for the determination of ultra-trace level of plutonium in high uranium samples (with $\mathrm{U} / \mathrm{Pu}$ atomic ratio $>10^{10}$ ), e.g. deep seawater, deep soil and sediment, uranium debris and scrap sample of nuclear fuel for forensics $\left({ }^{238} \mathrm{U} /{ }^{239} \mathrm{Pu}>1 \times 10^{10}\right)$. In addition, the multi-columns combination also make the chemical separation more complicated and time consuming.

HR-ICP -MS and ICP-MS-MC have been used for determination of plutonium isotopes and other actinides ${ }^{18,45}$. The most attractive feature of these instruments for measurement of plutonium isotope is its high sensitivity, a count rate of $6 \times 10^{7} \mathrm{cps} / \mathrm{ppb} \mathrm{U}$ was reported by using Apex-ICPSF-MS in low resolution model ${ }^{18}$, which is nearly one order of magnitude higher than ICP-MS or ICP-MS/MS instrument. Although an improved abundance sensitivity (up to $10^{-6}-10^{-7}$ ) can be reached in high resolution model, but still much lower than ICP-MS/MS instrument. Due to the small difference of mass between ${ }^{238} \mathrm{U}^{1} \mathrm{H}$ and ${ }^{239} \mathrm{Pu}\left(\Delta \mathrm{m} / \mathrm{m}=2.7 \times 10^{-5}\right)$, the HR-ICP-MS instrument could not effectively remove the interference of uranium hydrides in the measurement of plutonium isotopes. The dynamic collision/reaction cell (DRC) technology in the ICP-MS has shown a powerful feature to eliminate polyatomic ions. Different reaction gasses, such as $\mathrm{He}, \mathrm{O}_{2}$, $\mathrm{N}_{2} \mathrm{O}, \mathrm{NH}_{3}$ and $\mathrm{CO}_{2}$ have been proposed for removing uranium hydride ${ }^{27-31}$. We had investigated the application of $\mathrm{NH}_{3}-\mathrm{He}$ as reaction gas in the ICP-MS measurement of plutonium isotopes, and 
found that the elimination efficiency of uranium hydrides was improved by a factor of 15 compared to the ordinary method without reaction gas ${ }^{14}$, which is still not sufficient for the determination ultra-low level plutonium in the presence of high uranium. No detailed report on the application of other reaction gasses for ICP-MS measurement of femtogram level plutonium isotopes in samples containing high-level uranium is available. Desolvation technique (e.g. APEX) was often applied for reduced uranium hydride and improve the counting efficiency in the ICP-MS measurement of plutonium and other actinides $6,18,45$. It was found that this system can significantly improve the counting sensitivity by a factor of 7-10. Although an improvement on removal of uranium hydrides was observed in our experiment, but only 2-3 times suppression of $\mathrm{UH}^{+}$ions signal, which is not sufficient for the determination of plutonium isotopes in high uranium samples. ICP-MS/MS with two quadruple mass separators has been applied for determination of plutonium isotopes ${ }^{14,31}$. With this instrument, a better abundance sensitivity of up to $10^{-10}$ can be achieved, which can significantly remove the interference of the ${ }^{238} \mathrm{U}$ peak tailing in the measurement of ${ }^{239} \mathrm{Pu}$ and ${ }^{240} \mathrm{Pu}{ }^{14}$.

This work aims to develop a rapid and accurate analytical method for determination ultratrace level plutonium isotopes in high-level uranium samples by using a simple chemical separation combined with ICP-MS/MS equipped with DRC, in order to determine femtogram level ${ }^{239} \mathrm{Pu}$ and ${ }^{240} \mathrm{Pu}$ in high uranium samples such as seawater, soil, sediment and nuclear fuel debris. The most effort is dedicated to effectively eliminate interference of uranium using DRC with different reaction/collision gasses.

\section{EXPERIMENTAL SECTION}

Instrument and setup. Triple quadrupole ICP-MS (Agilent 8800, Agilent Technologies, Japan) 
was used for the measurement, it equips with an octopole DRC between two quadrupole mass separators. The first quadrupole (Q1) acts as an ion-guide to select the target ions (isotopes). The collision/reaction gas is introduced into the $\mathrm{DRC}$, to reacts with the entered ions for eliminating the interfering ions by forming new ions. The second quadrupole (Q2) acts as another mass-filter for selecting the target ions after the reactions in the DRC for their measurement in the followed detector (Figure S1). The instrument was tuned using ${ }^{238} \mathrm{U}$ (1.0 ppb natural uranium) and plutonium $\left({ }^{239} \mathrm{Pu}, 1.0 \mathrm{ppt}\right)$ standard solutions, the optimized parameters are shown in Table $\mathrm{S} 1$. The standard, simulated solution (isotope spiked) and separated plutonium samples were prepared in $0.5 \mathrm{~mol} / \mathrm{L}$ $\mathrm{HNO}_{3}$ for measurement, $\mathrm{In}^{3+}\left(\mathrm{InCl}_{3}, 1.0 \mathrm{ppb}\right)$ solution was used as an internal standard which was injected to the nebulizer using a T-valve. The sample and internal standard solution were introduced using peristaltic pump at $0.5 \mathrm{~mL} / \mathrm{min}$. Pt skimmer cone, s-lens, MicroMist Micro Flow 200 nebulizer and hot plasma were used in the measurement of plutonium isotopes. Four gas lines $\left(\mathrm{CO}_{2}, \mathrm{He}, \mathrm{NH}_{3}-\mathrm{He}\left(9.88 \% \mathrm{NH}_{3}\right)\right.$, and $\mathrm{O}_{2}$ gas, $99.999 \%$ purities $)$ to the DRC were used in this work. Chemical reagents and samples. ${ }^{242} \mathrm{Pu}$ standard solution $\left(70.0 \mathrm{pg} / \mathrm{mL}\right.$ in $\left.2.0 \mathrm{~mol} / \mathrm{L} \mathrm{HNO}_{3}\right)$ was prepared from ${ }^{242} \mathrm{Pu}$ standard reference materials of NIST-SRM-3443I (National Institute of Standard Technology, Gaithersburg, Maryland, USA). ${ }^{239} \mathrm{Pu}$ working solution (398 pg/mL in 2 $\mathrm{mol} / \mathrm{L} \mathrm{HNO}_{3}$ ) was prepared from a calibrated ${ }^{239} \mathrm{Pu}$ solution supplied by DTU Nutech (Denmark), and the standard solution of uranium was prepared from IRMM-184 uranium standard solution (Institute for reference materials and managements, Geel, Belgium). AG 1-×4 anion exchange resin (100-200 mesh, chloride form, Bio-Rad Laboratories Inc., California, USA) was used for separation of plutonium. All chemical reagents used in this work were high pure analytical grade reagents and prepared using deionized water $(18.2 \mathrm{M} \Omega \cdot \mathrm{cm})$.

To investigate the possible reactions in the reaction cell with different reaction gasses and to 
optimize parameters for effectively eliminating interference of ${ }^{238} \mathrm{U}^{1} \mathrm{H}^{+}$for measurement of ${ }^{239} \mathrm{Pu}^{+}$, uranium $(20$ and $1000 \mathrm{ng} / \mathrm{mL})$ and ${ }^{239} \mathrm{Pu}(10 \mathrm{pg} / \mathrm{mL})$ standard solutions were prepared, some $\mathrm{m} / \mathrm{z}$ values were selected in Q1 and Q2 as shown in Table S2 for ICP-MS measurement.

Two standard reference materials, Irish Sea sediment (IAEA-385) and soil (IAEA-327) were analyzed for verification of the method. Meanwhile, 4 surface soil samples $(0-5 \mathrm{~cm})$ and 2 deep soil samples $(25-30 \mathrm{~cm})$ collected from background areas in China were analyzed in this work.

Chemical separation of plutonium from environmental samples. A chemical separation procedure using acid leaching, co-precipitation and chromatographic separation (Figure S2) was used for separation of plutonium from the sample matrix and interfering radionuclides, the detailed method has been reported elsewhere ${ }^{14}$ and presented in the Supporting Information. In brief, a known amount of ${ }^{242} \mathrm{Pu}(3.4 \mathrm{pg})$ was spiked as chemical yield tracer to soil or sediment sample, the sample was leached with aqua regia. Ammonium was added to the leachate precipitate plutonium with iron and other metals as hydroxides. Plutonium in the precipitate was dissolved, converted to $\mathrm{Pu}^{4+}$ and prepared in $1.0 \mathrm{~mol} / 1 \mathrm{HNO}_{3}$ solution, which was loaded to a TEVA column. After rinsed the column with $1.0 \mathrm{~mol} / \mathrm{L} \mathrm{HNO}_{3}$ and $6 \mathrm{~mol} / \mathrm{L} \mathrm{HCl}$, plutonium on the column was eluted with $40 \mathrm{~mL}$ of $0.1 \mathrm{~mol} / \mathrm{L} \mathrm{NH}_{2} \mathrm{OH} \cdot \mathrm{HCl}$ in $2 \mathrm{~mol} / \mathrm{L} \mathrm{HCl}$. After decomposed $\mathrm{NH}_{2} \mathrm{OH} \cdot \mathrm{HCl}$ and prepared in $3.0 \mathrm{ml}$ of $0.5 \mathrm{~mol} / \mathrm{L} \mathrm{HNO}_{3}$ solution, plutonium isotopes were measured using ICPMS/MS.

\section{RESULTS AND DISCUSSION}

The collision/reaction gasses including $\mathrm{He}, \mathrm{NH}_{3}-\mathrm{He}, \mathrm{O}_{2}$ and $\mathrm{CO}_{2}$ were investigated for elimination of uranium hydride $\left({ }^{238} \mathrm{U}^{1} \mathrm{H}^{+}\right.$and ${ }^{238} \mathrm{U}^{1} \mathrm{H}_{2}{ }^{+}$). The results (Figure 1) show that injection of helium gas into the DRC could not suppress the intensities of ${ }^{238} \mathrm{U}^{+}$and ${ }^{238} \mathrm{U}^{1} \mathrm{H}^{+}$signal, but even 
increased ${ }^{238} \mathrm{U}^{+}$and ${ }^{238} \mathrm{U}^{1} \mathrm{H}^{+}$signal intensities with the increased flow rate of helium (Figure 1). This indicates that $\mathrm{UH}^{+}$ion could not be destroyed through collision reaction with helium.

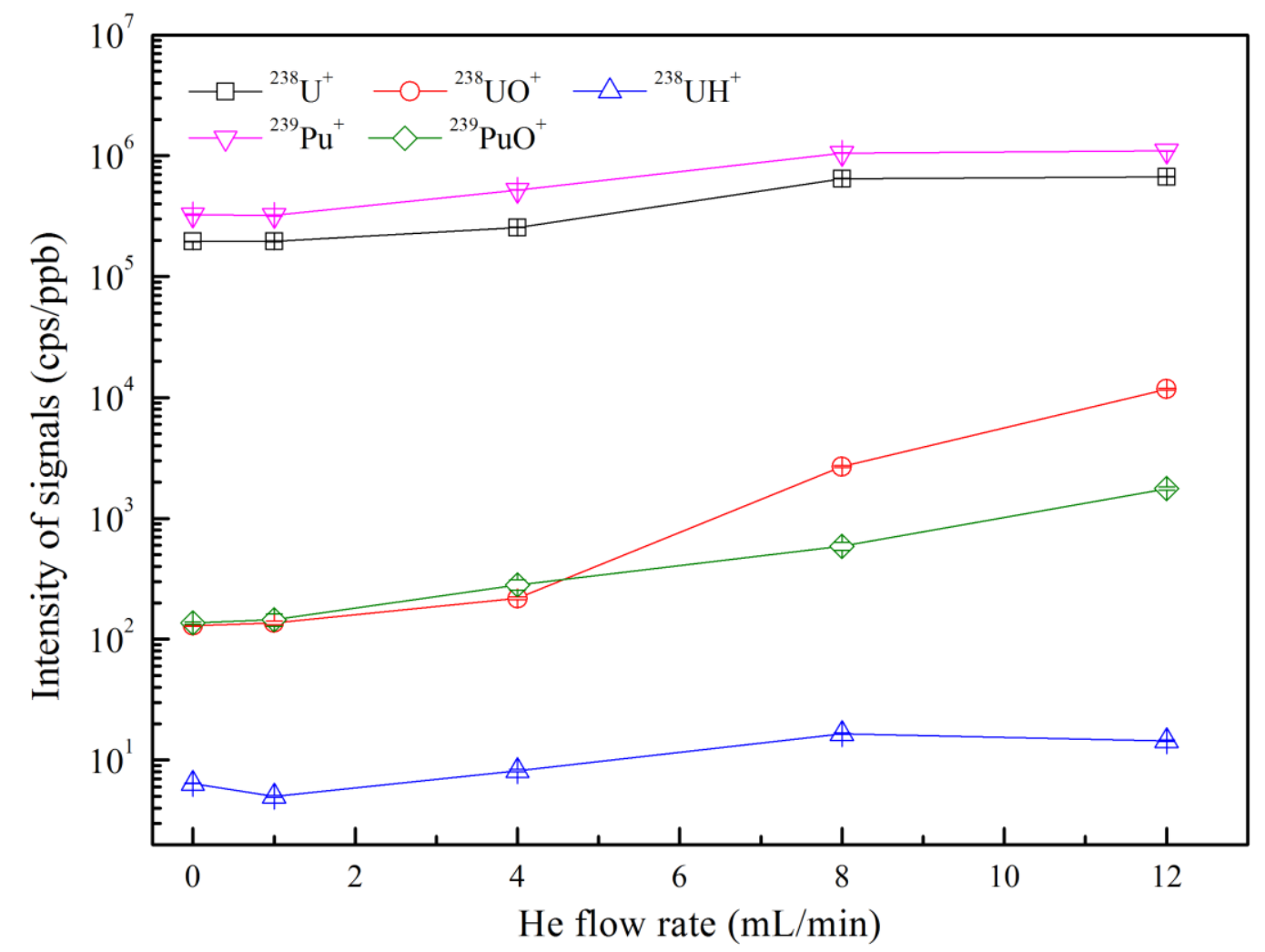

Figure 1 Variation of the intensities of $\mathrm{Pu}^{+}, \mathrm{PuO}^{+}, \mathrm{U}^{+}, \mathrm{UH}^{+}, \mathrm{UO}^{+}$ion with the flow rate of helium injected to the DRC. For $\mathrm{Pu}^{+}$and $\mathrm{PuO}^{+}$, the $\mathrm{m} / \mathrm{z}=239$ was selected in the Q1 (first quadrupole) and $\mathrm{m} / \mathrm{z}=239$ and 255 in the $\mathrm{Q} 2$ (second quadrupole), respectively; for $\mathrm{U}^{+}$and $\mathrm{UO}^{+}$, the $\mathrm{m} / \mathrm{z}=238$ was selected in the $\mathrm{Q} 1$ and $\mathrm{m} / \mathrm{z}=238$ and 254 in the Q2, respectively; for $\mathrm{UH}^{+}$, $\mathrm{m} / \mathrm{z}=239$ was selected in both $\mathrm{Q} 1$ and $\mathrm{Q} 2$.

The results using $\mathrm{O}_{2}$ as a reaction gas (Figure S3) show that the intensity of ${ }^{238} \mathrm{U}^{+}$signal was significantly reduced with the increased flow rate of $\mathrm{O}_{2}$. Meanwhile, intensive signals of ${ }^{238} \mathrm{U}^{16} \mathrm{O}^{+}$ $(\mathrm{m} / \mathrm{z}=254)$ was measured when the flow rate of $\mathrm{O}_{2}$ was increased to $0.5 \mathrm{ml} / \mathrm{ml}$, and then decreased 
with an increased flow rate of $\mathrm{O}_{2}$. This implies that ${ }^{238} \mathrm{U}^{16} \mathrm{O}_{2}{ }^{+}$was formed with increased $\mathrm{O}_{2}$ flow rate ${ }^{29}$. The intensity of ${ }^{238} \mathrm{U}^{1} \mathrm{H}^{+}$ion also significantly reduced with the increased flow rate of $\mathrm{O}_{2}$. The remarkably increased intensity of ${ }^{238} \mathrm{U}^{16} \mathrm{O}^{+}$was observed when $\mathrm{m} / \mathrm{z}=239\left({ }^{238} \mathrm{U}^{1} \mathrm{H}\right)$ was selected in Q1, but $\mathrm{UHO}^{+}$ions (Q1(238)/Q2(255) was still measurable (Table S3). This indicates that $\mathrm{U}^{+}$and $\mathrm{UH}^{+}$ions react with $\mathrm{O}_{2}$ to form $\mathrm{UO}^{+}$and $\mathrm{UO}_{2}{ }^{+}$, and a small fraction of $\mathrm{UH}^{+}$ion was converted to $\mathrm{UHO}^{+}$. However, the intensity of $\mathrm{Pu}^{+}$ion also decreased in the same order of magnitude as ${ }^{238} \mathrm{U}^{+}$with the injection of $\mathrm{O}_{2}$. Meanwhile, the intensities of $\mathrm{PuO}^{+}$signal increased with the increased flow rate of $\mathrm{O}_{2}$ (Figure $\mathrm{S} 3$ ). This indicates that $\mathrm{Pu}^{+}$can also react with $\mathrm{O}_{2}$ to form $\mathrm{PuO}^{+}$. In this case, the peak tailing of ${ }^{238} \mathrm{U}^{16} \mathrm{O}^{+}$and ${ }^{238} \mathrm{U}^{16} \mathrm{O}^{1} \mathrm{H}^{+}$and ${ }^{238} \mathrm{U}^{16} \mathrm{O}^{1} \mathrm{H}_{2}{ }^{+}$become the dominant interferences for measurement of ${ }^{239} \mathrm{Pu}^{16} \mathrm{O}^{+}$and ${ }^{240} \mathrm{Pu}^{16} \mathrm{O}^{+}$ions, causing a less efficient elimination of the uranium interference.

Ammonia as a reaction gas has been investigated for the elimination of uranium interference ${ }^{14}$. It was observed that the intensity of $\mathrm{UH}^{+}$signal decreased with the flow rate of $\mathrm{NH}_{3}$ (Figure S4) due to the formation of $\mathrm{UNH}_{2}{ }^{+}$ions $(\mathrm{m} / \mathrm{z}=255)$ (Table S3) $)^{14}$. While, the intensity of $\mathrm{Pu}^{+}$was not significantly reduced with the increased flow rate of $\mathrm{NH}_{3}$ (Figure $\mathrm{S} 4$, Table $\mathrm{S} 4$ ) due to no reaction of $\mathrm{Pu}^{+}$with $\mathrm{NH}_{3}$. Therefore, $\mathrm{NH}_{3}$ was successfully used to eliminate uranium interference ${ }^{14}$. However, $\mathrm{UH}^{+}$could not be completely removed, makes it not sufficient for the determination of low-level ${ }^{239} \mathrm{Pu}$ in high uranium samples.

$\mathrm{CO}_{2}$ has also been proposed as a reaction gas for the elimination of the uranium interference ${ }^{27,28,30}$. The results show that $\mathrm{CO}_{2}$ highly suppressed the signals of ${ }^{238} \mathrm{U}^{+}$and ${ }^{238} \mathrm{U}^{1} \mathrm{H}^{+}$, while only part of $\mathrm{Pu}^{+}$reacted with $\mathrm{CO}_{2}$ to form $\mathrm{PuO}^{+}$ions (Figure 2).

Elimination of uranium interference using $\mathrm{CO}_{2}-\mathrm{He}$ as reaction/collision gasses. It was observed that the intensities of $\mathrm{U}^{+}$ions decreased exponentially with the increased flow rate of 
$\mathrm{CO}_{2}$ injected to the DRC by 3 orders of magnitude when the flow rate of $\mathrm{CO}_{2}$ was increased to 1.2 $\mathrm{ml} / \mathrm{min}$ (Figure 2). Meanwhile, extensive $\mathrm{UO}^{+}$signal was observed (Figure 2, Table S3), indicating $\mathrm{U}^{+}$and $\mathrm{UH}^{+}$react with $\mathrm{CO}_{2}$ to form $\mathrm{UO}^{+}$. Following a rapidly increased intensity of $\mathrm{UO}^{+}$signal with the injection of $\mathrm{CO}_{2}$, the intensity of $\mathrm{UO}^{+}$signal gradually decreased with the increased flow rate of $\mathrm{CO}_{2}$ from $0.5 \mathrm{ml} / \mathrm{min}$ (Figure 2), this should be attributed to the formation of $\mathrm{UO}_{2}{ }^{+}$ions, and the intensity of $\mathrm{UO}_{2}{ }^{+}$ion increased with the increased flow rate of $\mathrm{CO}_{2}{ }^{27}$.

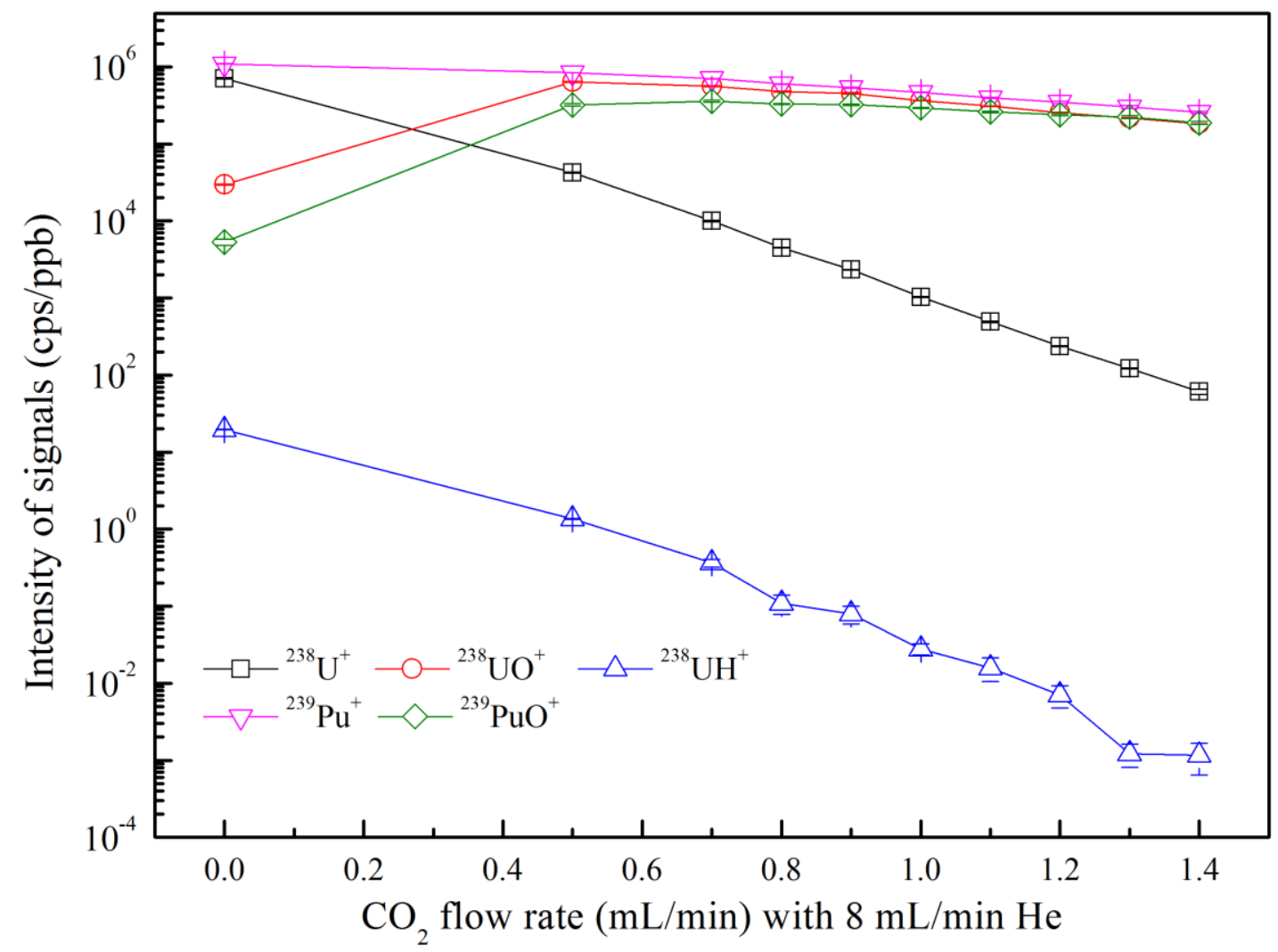

Figure 2 Variation of the intensities of $\mathrm{U}^{+}, \mathrm{UH}^{+}, \mathrm{UO}^{+}, \mathrm{Pu}^{+}$and $\mathrm{PuO}^{+}$ions with the flow rate of $\mathrm{CO}_{2}$ with $8 \mathrm{ml} / \mathrm{min}$ helium injected to the DCR. For $\mathrm{U}^{+}$and $\mathrm{UO}^{+}$ions, $\mathrm{m} / \mathrm{z}=238$ was selected in Q1 (the first quadrupole) and $\mathrm{m} / \mathrm{z}=238$ and 254 in the Q2 (second quadrupole), respectively; For $\mathrm{UH}^{+}, \mathrm{Pu}^{+}$and $\mathrm{PuO}^{+}, \mathrm{m} / \mathrm{z}=239$ was selected in $\mathrm{Q} 1$ and $\mathrm{m} / \mathrm{z}=239,239$, and 255, respectively. ${ }^{239} \mathrm{Pu}$ standard solution of $2.0 \mathrm{pg} / \mathrm{ml}$ and Uranium standard solution of $20 \mathrm{ng} / \mathrm{mL}$ and $1000 \mathrm{ng} / \mathrm{mL}$ (for $\mathrm{UH}^{+} / \mathrm{UH}^{+}$) were used in this measurement. 
It is interesting that the intensity of $\mathrm{UH}^{+}$ion shows the same exponentially decreased trend as $\mathrm{U}^{+}$ion with the increased flow rate of $\mathrm{CO}_{2}$ (Figure 2), indicating that $\mathrm{UH}^{+}$can be destroyed ${ }^{+}$by reaction with $\mathrm{CO}_{2}$ in the $\mathrm{DRC}$ through the formation of $\mathrm{UO}^{+}$and $\mathrm{UO}_{2}^{+}$. About $10^{4}$ reduction of $\mathrm{UH}^{+}$signal was achieved at $1.3 \mathrm{ml} / \mathrm{min} . \mathrm{CO}_{2}$ injection, further increasing flow rate of $\mathrm{CO}_{2}$ does not significantly reduce the $\mathrm{UH}^{+}$signal.

It was observed that the intensity of $\mathrm{Pu}^{+}$signal decreases slowly with the increased flow rates of $\mathrm{CO}_{2}$, and reach to about $1 / 3$ intensity of the original one (without $\mathrm{CO}_{2}$ but only $8 \mathrm{ml} / \mathrm{min} \mathrm{He}$ ) at $1.2 \mathrm{ml} / \mathrm{ml} \mathrm{CO}_{2}$ (Figure 2). Meanwhile, the increased signal of ${ }^{239} \mathrm{Pu}^{16} \mathrm{O}^{+}($at $\mathrm{m} / \mathrm{z}=255)$ was observed with the injection of $\mathrm{CO}_{2}$. However, with the increased flow rate of $\mathrm{CO}_{2}$, the intensity of $\mathrm{PuO}^{+}$ signal showed a similar declining trend as $\mathrm{Pu}^{+}$signal (Figure 2). This should be attributed to the enhanced formation of $\mathrm{PuO}_{2}{ }^{+}$at a high flow rate of $\mathrm{CO}_{2}$ in the $\mathrm{DRC}{ }^{27}$.

It was found that the flow rate of helium has a significate influence on the intensity of $\mathrm{Pu}^{+}$ signal (Figure 3). With $1.2 \mathrm{ml} / \mathrm{min} \mathrm{CO}_{2}$, the intensity of $\mathrm{Pu}^{+}$signal increased with the increased flow rate of helium and reaches to a maximum value at $8 \mathrm{ml} / \mathrm{min}$, and then decreases. Therefore, the flow rate of $8 \mathrm{ml} / \mathrm{min}$ for helium was selected as assistant/second gas. Meanwhile, the intensity of $\mathrm{PuO}^{+}$ions decreases significantly with the increased flow rate of helium. This might be attributed to the reduced reactivity of $\mathrm{CO}_{2}$ with $\mathrm{Pu}^{+}$ion to form $\mathrm{PuO}^{+}$in the increased flow rate of helium, and consequently causing the increased $\mathrm{Pu}^{+}$signal intensity. It was also observed that the intensities of $\mathrm{Pu}^{+}$and $\mathrm{U}^{+}$signals increased for about 3 times when only helium was injected from 0 to $8.0 \mathrm{ml} / \mathrm{min}$ and then keep relative constant when further increasing the flow rate of He (Figure 1). Therefore, the increased intensity of $\mathrm{Pu}^{+}$with the increased flow rate of helium in the presence of $\mathrm{CO}_{2}$ should be attributed to the helium injected to the $\mathrm{DRC} . \mathrm{Pu}^{+}$ions from the plasma through the first quadrupole has a relatively high and large expanded kinetic energy $(0-20 \mathrm{eV})$, elastic 
collision of these ions with helium atoms reduced their kinetic energy to about $2 \mathrm{eV}$ and narrowed distribution of the ion kinetic energy $(0-3 \mathrm{eV})$, which significantly improved ion focusing, and consequently increased the numbers of ions counted in the detector, i.e. measurement sensitivity ${ }^{8,31}$. The improved intensity of $\mathrm{Pu}^{+}$by collision focusing of the injected helium gas compensate the loss of $\mathrm{Pu}^{+}$signal intensity by partly forming $\mathrm{PuO}^{+}$in the $\mathrm{DRC}$, and makes the intensity of $\mathrm{Pu}^{+}$signal in the same level (about $3.4 \times 10^{5} \mathrm{cps} / \mathrm{ppb}$ ) at the reaction gasses of $1.2 \mathrm{~mL} / \mathrm{min} \mathrm{CO}_{2}-8 \mathrm{~mL} / \mathrm{min} \mathrm{He}$ as that in no gas mode. It was also observed that the intensities of $\mathrm{UH}^{+}$signal significantly decreased with the increased flow rate of helium (Figure 3), which helps the elimination of uranium hydride interference. Based on the above experimental results, $1.2 \mathrm{~mL} / \mathrm{min} \mathrm{CO}_{2}-8.0 \mathrm{~mL} / \mathrm{min} \mathrm{He}$ was selected as the optimal condition for the elimination of uranium interference and sensitive measurement of plutonium isotopes.

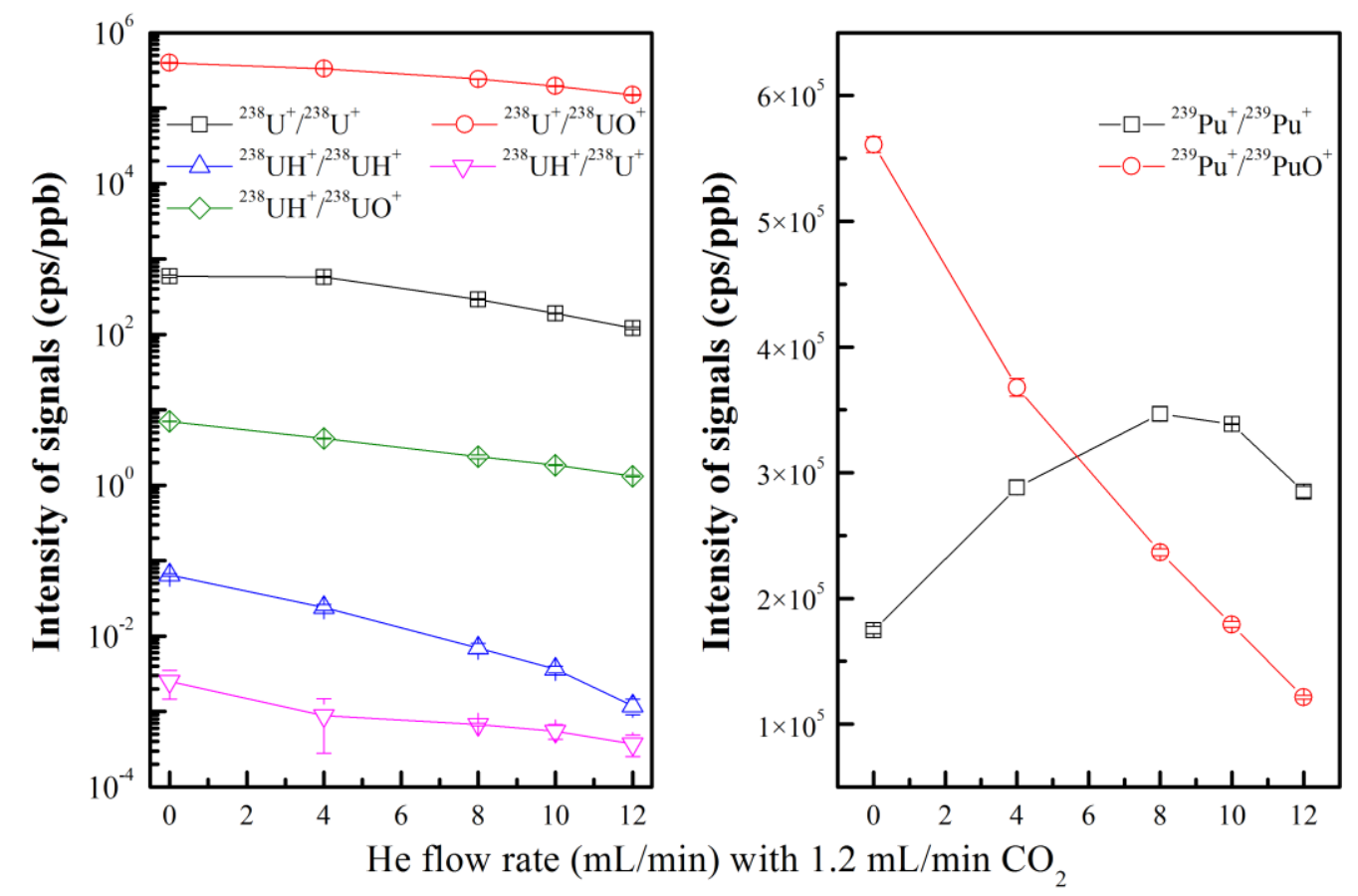

Figure 3 Influence of flow rate of helium injected to the DRC with $1.2 \mathrm{ml} / \mathrm{min} \mathrm{CO}_{2}$ on the intensities of the $\mathrm{Pu}^{+}, \mathrm{PuO}^{+}, \mathrm{U}^{+}, \mathrm{UH}^{+}$and $\mathrm{UO}^{+}$ions. ${ }^{238} \mathrm{UH}^{+} / 238 \mathrm{UO}^{+}$in the legend means that $\mathrm{m} / \mathrm{z}=239\left({ }^{238} \mathrm{UH}^{+}\right)$was selected for the first Quadrupole $(\mathrm{Q} 1)$ and $\mathrm{m} / \mathrm{z}=255\left({ }^{238} \mathrm{U}^{16} \mathrm{O}^{+}\right)$was 
selected in the second quadrupole (Q2) mass separator, others are the similar meaning. The left figure is the measurement of a uranium standard solution, and the right figure is the measurement of a ${ }^{239} \mathrm{Pu}$ standard solution. Note: the uncertainties presented in some data points are too small to be clearly visible.

These observations also indicate that $\mathrm{CO}_{2}$ has high reactivity with $\mathrm{U}^{+}$and $\mathrm{UH}^{+}$compared to $\mathrm{Pu}^{+}$, this can be explained by the thermodynamics of oxidation reaction of $\mathrm{U}^{+}$and $\mathrm{Pu}^{+}$with oxidizing reagents (i.e. $\mathrm{NH}_{3}, \mathrm{CO}_{2}$ and $\mathrm{O}_{2}$ ). The reported efficiencies of the reactions of $\mathrm{Pu}^{+}$(related to the bond dissociation energy of $\mathrm{PuO}^{+}$and the oxidizing reagents of $\mathrm{CO}_{2}$ and $\mathrm{O}_{2}$ ) are 0.003 for $\mathrm{CO}_{2}$ and 0.27 for $\mathrm{O}_{2}$. While the efficiencies of reactions of $\mathrm{U}^{+}$with $\mathrm{CO}_{2}$ and $\mathrm{O}_{2}$ are 0.29 and 0.72 , respectively ${ }^{32}$. The higher of the reaction efficiency is the stronger of the reactivity, this explains why only fraction of $\mathrm{Pu}^{+}$was oxidized to $\mathrm{PuO}^{+}$by $\mathrm{CO}_{2}$, but almost all $\mathrm{U}^{+}$was oxidized to $\mathrm{UO}^{+}$and $\mathrm{UO}_{2}{ }^{+}$by $\mathrm{CO}_{2}$ and $\mathrm{O}_{2}$. The relative high reaction of $\mathrm{CO}_{2}$ with $\mathrm{U}^{+}$compared to $\mathrm{Pu}^{+}$could be also explained by the reaction kinetics ${ }^{32}$. The oxidation of $\mathrm{U}^{+}$and $\mathrm{Pu}^{+}$requires to promote the groundstate ions to a reactive configuration containing two unpaired non-f-orbital electrons. $\mathrm{U}^{+}$requires only $0.04 \mathrm{eV}$ energy to promote a $7 \mathrm{~s}$ electron to $6 \mathrm{~d}$ orbit, while $\mathrm{Pu}^{+}$needs to promote a $5 \mathrm{f}$ electron to $6 \mathrm{~d}$ orbit, which requires higher energy of $1.08 \mathrm{eV}$, and shows an activation energy barrier to the reaction. Therefore, only a fraction of $\mathrm{Pu}^{+}$could be oxidized to $\mathrm{PuO}^{+}$by $\mathrm{CO}_{2}$ and the formation of $\mathrm{PuO}^{+}$increases with the increased flow rate of $\mathrm{CO}_{2}$.

Both peak tailing of ${ }^{238} \mathrm{U}$ and the uranium hydride ion $\left({ }^{238} \mathrm{U}^{1} \mathrm{H}^{+}\right)$contribute to the signal at $\mathrm{m} / \mathrm{z}$ $=239$ in ICP-MS measurement of ${ }^{239} \mathrm{Pu}$. But it is impossible to discriminate and directly measure these two contributions. Since the ${ }^{238} \mathrm{U}$ peak causes tailings to both low $(\mathrm{m}-1)$ and high $(\mathrm{m}+1)$ sides in the mass spectrum (abundance sensitivity), and the low side (m-1) normally receives a higher 
tailing contribution compared to the high $(\mathrm{m}+1)$ side $^{8}$. Monitoring the signal intensity at $\mathrm{m} / \mathrm{z}=237$ can estimate the contribution of ${ }^{238} \mathrm{U}$ tailing to the $\mathrm{m} / \mathrm{z}=239$. Table 1 shows the measured abundance sensitivities of ${ }^{238} \mathrm{U}$ to $\mathrm{m} / \mathrm{z}=237$ in single quadrupole mode (the Q1 was closed and only Q2 was used) and tandem quadrupoles modes ( $\mathrm{m} / \mathrm{z}=237$ was selected in both quadrupoles) and using different collision/reaction gasses in the DRC. The best abundance sensitivity of $4 \times 10^{-7}$ in the single quadrupole mode was achieved by using $\mathrm{CO}_{2}-\mathrm{He}$ as reaction gas. This is mainly attributed to the highly removal of ${ }^{238} \mathrm{U}^{+}$ions by oxidizing it to $\mathrm{UO}^{+}$and $\mathrm{UO}_{2}{ }^{+}$, collision focusing of ${ }^{238} \mathrm{U}^{+}$by helium atoms in the DRC also helps to reduce the tailing contribution to $\mathrm{m} / \mathrm{z}=237$ and $239^{8}$. An extensive suppression of tailing effect (abundance sensitivity) down to $<1.6 \times 10^{-11}$ was achieved by using two tandem quadrupole mode and $1.2 \mathrm{~mL} / \mathrm{min} \mathrm{CO}_{2}-8.0 \mathrm{~mL} / \mathrm{min} \mathrm{He}$ as the reaction/collision gas. The intensity of signal at $\mathrm{m} / \mathrm{z}=237$ was reduced to undetectable (not significant difference compared to the procedure blank) when measuring a $1 \times 10^{-6} \mathrm{~g} / \mathrm{mL}$ uranium solution. It means that the interference of ${ }^{238} \mathrm{U}^{+}$tailing to the measurement of ${ }^{239} \mathrm{Pu}$ and ${ }^{240} \mathrm{Pu}$ is negligible, and the major interference should be the hydrides of uranium $\left({ }^{238} \mathrm{U}^{1} \mathrm{H}^{+}\right.$and $\left.{ }^{238} \mathrm{U}^{1} \mathrm{H}_{2}{ }^{+}\right)$.

The level of elimination of uranium hydride $\left({ }^{238} \mathrm{U}^{1} \mathrm{H}^{+}\right.$and $\left.{ }^{238} \mathrm{U}^{1} \mathrm{H}_{2}{ }^{+}\right)$using ICP-MS/MS with different reaction gas was estimated by measurement of a $1 \times 10^{-6} \mathrm{~g} / \mathrm{mL}$ uranium standard solution and monitoring the intensity of signals at $\mathrm{m} / \mathrm{z}=239$ and 240 . The signal intensities at $\mathrm{m} / \mathrm{z}=239$ and 240 were compared with the highest intensity of ${ }^{238} \mathrm{U}^{+}$in the corresponding condition, i.e. the ${ }^{238} \mathrm{U}^{+}$ ion intensity in no gas was used for the modes of no gas and $\mathrm{O}_{2}$, and the ${ }^{238} \mathrm{U}^{+}$ion intensity in 8.0 $\mathrm{ml} / \mathrm{min}$ helium gas was used for the modes of $\mathrm{He}, \mathrm{NH}_{3}-\mathrm{He}$ and $\mathrm{CO}_{2}-\mathrm{He}$. The results (Table 2) shows that both $\mathrm{O}_{2}$ and $\mathrm{NH}_{3}-\mathrm{He}$ mode can reach to ${ }^{238} \mathrm{U}^{1} \mathrm{H}^{+} / 238 \mathrm{U}^{+}$ratio of $1 \times 10^{-6}$, and the best elimination of uranium hydride was achieved by using $1.2 \mathrm{ml} / \mathrm{min} \mathrm{CO}_{2}-8.0 \mathrm{ml} / \mathrm{min} \mathrm{He}$ as reaction gas in ICP-MS/MS measurement, reach to $1.2 \times 10^{-8}$ for ${ }^{238} \mathrm{U}^{1} \mathrm{H}^{+} / 238 \mathrm{U}^{+}$ratio and $<2 \times 10^{-11}$ for 
${ }^{238} \mathrm{U}^{1} \mathrm{H}_{2}{ }^{+} / 238 \mathrm{U}^{+}$. They are 50-1000 times improvement compared to the previously reported values in the ICP-MS measurement of ${ }^{239} \mathrm{Pu}$ using different instruments and setups (Table 2). This value is also 100 times better than the newly reported ICP-MS/MS using $\mathrm{NH}_{3}-\mathrm{He}$ as reaction gas ${ }^{14}$. This result suggests that this method can measure ${ }^{239} \mathrm{Pu}$ in a sample solution containing at least $10^{7}$ times higher uranium. In summary, the developed method for determination of ${ }^{239} \mathrm{Pu}$ and ${ }^{240} \mathrm{Pu}$ using ICP-MS/MS is more than $10^{4}$ times better than the ordinary single quadrupole mass separator in view of elimination of the ${ }^{238} \mathrm{U}^{+}$tailing and more than 1000 times better in view of the elimination of uranium hydrides interference by employing $\mathrm{CO}_{2}-\mathrm{He}$ as reaction gas in the $\mathrm{DRC}$, which is also effective for removal of interference of other polyatomic ions.

\section{Verification of the developed method for determination of low-level ${ }^{239} \mathrm{Pu}$ and ${ }^{240} \mathrm{Pu}$ in high}

uranium solution. Simulated solution containing $1 \times 10^{-14} \mathrm{~g} / \mathrm{mL}$ of ${ }^{239} \mathrm{Pu}$ and $(0.010-988) \times 10^{-9}$ $\mathrm{g} / \mathrm{mL}$ of uranium was analyzed using the developed ICP-MS/MS method. The results (Table 3) show that the ${ }^{239} \mathrm{Pu}$ in a concentration as low as $1 \times 10^{-14} \mathrm{~g} / \mathrm{mL}$ can be accurately measured in a solution containing $1 \times 10^{-7} \mathrm{~g} / \mathrm{mL}$ uranium (i.e. $\mathrm{Pu} / \mathrm{U}$ atomic ratio of $1 \times 10^{-7}$ ) using $1.2 \mathrm{~mL} / \mathrm{min} \mathrm{CO}_{2}$ $8.0 \mathrm{ml} / \mathrm{min} \mathrm{He}$ as reaction gas. This confirms that the developed method can be successfully used to measure ultra-low level ${ }^{239} \mathrm{Pu}$ in more than $10^{7}$ times higher uranium solution. Even for a solution with $\mathrm{Pu} / \mathrm{U}$ atomic ratio down to $1 \times 10^{-8},{ }^{239} \mathrm{Pu}$ was measured to be $(13.0 \pm 2.4) \times 10^{-15} \mathrm{~g} / \mathrm{mL}$ after a correction by subtraction of the contribution of uranium hydride $\left({ }^{238} \mathrm{U}^{1} \mathrm{H}^{+}\right)$, which is reasonably good agreement compared with the spiked ${ }^{239} \mathrm{Pu}$ of $10.1 \times 10^{-15} \mathrm{~g} / \mathrm{mL}$. While, for the ICP-MS/MS methods using other reaction gas, ${ }^{239} \mathrm{Pu}$ of $10 \times 10^{-15} \mathrm{~g} / \mathrm{mL}$ can be only accurately measured in the sample with less than $1 \times 10^{-9} \mathrm{~g} / \mathrm{mL}$ uranium, i.e. with $\mathrm{Pu} / \mathrm{U}$ atomic ratio higher than $1 \times 10^{-5}$. This demonstrated that the elimination efficiency of uranium hydride was improved 
by a factor of more than 100 in the developed method compared to the previously reported methods.

In ICP-MS measurement, other polyatomic ions with $\mathrm{m} / \mathrm{z}=239$ and 240 also interfere with the measurement of ${ }^{239} \mathrm{Pu}$ and ${ }^{240} \mathrm{Pu}$. The most important ones are those polyatomic ions of $\mathrm{Hg}, \mathrm{Tl}$ and $\mathrm{Pb}$ with $\mathrm{Ar}$, $\mathrm{Cl}$, $\mathrm{S}$ and $\mathrm{O}$, such as ${ }^{206} \mathrm{~Pb}^{33} \mathrm{~S}^{+},{ }^{207} \mathrm{~Pb}^{16} \mathrm{O}_{2}{ }^{+208} \mathrm{~Pb}^{31} \mathrm{P}^{+},{ }^{205} \mathrm{Tl}^{34} \mathrm{~S}^{+},{ }^{205} \mathrm{Hg}^{35} \mathrm{Cl}^{+},{ }^{202} \mathrm{Hg}^{37} \mathrm{Cl}^{+}$, ${ }^{199} \mathrm{Hg}^{40} \mathrm{Ar}+,{ }^{203} \mathrm{Tl}^{36} \mathrm{Ar}^{+},{ }^{204} \mathrm{~Pb}^{35} \mathrm{Cl}^{+}$for ${ }^{239} \mathrm{Pu}$, and ${ }^{204} \mathrm{~Pb}^{36} \mathrm{Ar}^{+},{ }^{206} \mathrm{~Pb}^{34} \mathrm{~S}^{+},{ }^{207} \mathrm{~Pb}^{33} \mathrm{~S}^{+},{ }^{208} \mathrm{~Pb}^{32} \mathrm{~S}^{+}$, ${ }^{203} \mathrm{Tl}^{36} \mathrm{Ar}^{+},{ }^{205} \mathrm{Tl}^{35} \mathrm{Cl}^{+},{ }^{203} \mathrm{Tl}^{37} \mathrm{Cl}^{+},{ }^{200} \mathrm{Hg}^{40} \mathrm{Ar}^{208} \mathrm{~Pb}^{16} \mathrm{O}_{2}{ }^{+}$for ${ }^{240} \mathrm{Pu}^{24}$. The analysis of $5 \times 10^{-7} \mathrm{~g} / \mathrm{mL} \mathrm{Pb}$ and $\mathrm{Tl}$ in $0.1 \mathrm{~mol} / \mathrm{L} \mathrm{HCl}$ and $0.5 \mathrm{~mol} / \mathrm{L} \mathrm{HNO}_{3}$ solution showed that the signal intensities observed at $\mathrm{m} / \mathrm{z}=239$ are less than $0.07 \mathrm{cps}$ and $0.03 \mathrm{cps}$ for $\mathrm{HCl}$ and $\mathrm{HNO}_{3}$ media, respectively, which is not significantly higher than that observed in the blank of only $0.5 \mathrm{~mol} / \mathrm{L} \mathrm{HNO}_{3}$ solution (Table S5). This indicates that the developed ICP-MS/MS method can also sufficiently eliminate the interferences of these polyatomic ions of $\mathrm{Pb}$ and $\mathrm{Tl}$. However, a remarkable interferences of polyatomic ions of $\mathrm{Hg}$ was observed when no reaction gas or helium gas was applied. A significant elimination of this interference for the measurement of ${ }^{239} \mathrm{Pu}$ and ${ }^{240} \mathrm{Pu}$ was achieved when $\mathrm{CO}_{2}$ $\mathrm{He}$ and $\mathrm{NH}_{3}-\mathrm{He}$ were applied as reaction gas. The measurement of $5 \times 10^{-7} \mathrm{~g} / \mathrm{mL} \mathrm{Hg}$ in $0.1 \mathrm{~mol} / \mathrm{L}$ $\mathrm{HCl}-0.5 \mathrm{~mol} / \mathrm{L} \mathrm{HNO}_{3}$ solution showed an signal intensity of $1.9 \pm 0.3 \mathrm{cps}$ at $\mathrm{m} / \mathrm{z}=239$, but not significant increased signal at $\mathrm{m} / \mathrm{z}=239$ for $\mathrm{Hg}-3 \% \mathrm{HNO}_{3}$ compared to the $3 \% \mathrm{HNO}_{3}$ blank was observed. Meanwhile, no significantly increased signal at $\mathrm{m} / \mathrm{z}=240$ was observed for $\mathrm{Hg}-0.1 \mathrm{M}$ $\mathrm{HCl}-3 \% \mathrm{HNO}_{3}$ and $\mathrm{Hg}-3 \% \mathrm{HNO}_{3}$, compared to $3 \% \mathrm{HNO}_{3}$ blank solution was observed. The 27 times higher signal intensity at $\mathrm{m} / \mathrm{z}=239$ observed in $\mathrm{Hg}-0.1 \mathrm{M} \mathrm{HCl}-3 \% \mathrm{HNO}_{3}$ solution compared to that in $\mathrm{Hg}-3 \% \mathrm{HNO}_{3}$ and $3 \% \mathrm{HNO}_{3}$ blank $(0.07 \mathrm{cps})$ indicates that ${ }^{202} \mathrm{Hg}^{37} \mathrm{Cl}^{+}$polyatomic ion cannot be completely eliminated in the reaction cell using $\mathrm{CO}_{2}-\mathrm{He}$ gas. The measurement results also showed that $\mathrm{Hg}$ does not form $\mathrm{HgO}^{+}$in the presence of $\mathrm{CO}_{2}$ in the reaction cell, implying a less efficiency to decompose the $\mathrm{HgCl}^{+}$ions in the reaction cell by oxidation reaction. Therefore, 
$\mathrm{Cl}^{-}$or $\mathrm{HCl}$ should be avoid/eliminated in the finally prepared plutonium solution for ICP-MS measurement. In the $\mathrm{HNO}_{3}$ media, no measurable interference of $\mathrm{Hg}, \mathrm{Tl}$ and $\mathrm{Pb}$ to the measurement of plutonium isotopes was observed in the developed method.

Chemical separation was applied to pre-concentrate plutonium from big samples and remove matric and interfering elements. In this work, plutonium was first leached by acids followed by separation of plutonium using co-precipitation and extraction chromatography using TEVA resin (Figure S2), and finally prepared in a small volume $(3 \mathrm{~mL})$ of $\mathrm{HNO}_{3}$ solution without salt $(<1 \mathrm{mg})$ for ICP-MS measurement. Meanwhile, uranium and other interfering elements $(\mathrm{Pb}, \mathrm{Hg}, \mathrm{Tl}, \mathrm{Cl})$ can also highly removed. A decontamination factor of (1-2) $\times 10^{5}$ for uranium was achieved.

A simulated solution containing $4 \mathrm{mg} / \mathrm{mL}^{238} \mathrm{U}$ and $4 \times 10^{-15} \mathrm{~g} / \mathrm{mL}^{239} \mathrm{Pu}\left({ }^{239} \mathrm{Pu} /{ }^{238} \mathrm{U}=1 \times 10^{-12}\right)$ was analyzed using the developed method employing chemical separation for determination of ${ }^{239} \mathrm{Pu}$ and ${ }^{242} \mathrm{Pu}$. The analytical results (Table $\mathrm{S} 6$ ) show that the measured ${ }^{239} \mathrm{Pu}$ value $\left((4.12 \pm 0.31) \times 10^{-15},(4.23 \pm 0.32) \times 10^{-15} \mathrm{~g} / \mathrm{mL}\right.$ and $\left.(4.16 \pm 0.35) \times 10^{-15} \mathrm{~g} / \mathrm{mL}\right)$ agree well with the spiked value $\left((4.10 \pm 0.05) \times 10^{-15} \mathrm{~g} / \mathrm{mL}\right)$, confirmed that the developed analytical method including chemical separation and ICP-MS/MS measurement is reliable for determination of femtogram level ${ }^{239} \mathrm{Pu}$ in an extremely high uranium samples (with a $\mathrm{U} / \mathrm{Pu}$ ratio up to $1 \times 10^{12}$ ).

Two certified reference materials (soil IAEA-327 and sediment IAEA-385) were analyzed for ${ }^{239} \mathrm{Pu}$ and ${ }^{240} \mathrm{Pu}$ using the developed method. The analytical results (Table 4) show that the measured concentrations of ${ }^{239} \mathrm{Pu}$ and ${ }^{240} \mathrm{Pu}$ agree well with the reference values and the reported values $^{33}$ in IAEA-385 $(\mathrm{p}<0.01) .{ }^{239} \mathrm{Pu}$ and ${ }^{240} \mathrm{Pu}$ were not certified in IAEA-327, but the analytical results in this work agree very well with the reported values in the literature for IAEA-327 34 $(\mathrm{p}<0.01)$. These analytical results confirmed that the analytical method presented in this paper is reliable for the determination of low-level ${ }^{239} \mathrm{Pu}$ and ${ }^{240} \mathrm{Pu}$ in environmental and forensic samples 
with high-level uranium.

Procedure blanks were prepared and analyzed using the same method as the samples, the analytical results (Table 4) show constantly small signals of $0.15 \pm 0.03 \mathrm{cps}$ at $\mathrm{m} / \mathrm{z}=239$ and $0.04 \pm 0.02$ cps at $\mathrm{m} / \mathrm{z}=240(\mathrm{n}=3$, procedure blanks), only 2 times higher than those measured in 0.5 $\mathrm{mol} / \mathrm{L} \mathrm{HNO}_{3}$ solution (used for preparing samples). The signal at $\mathrm{m} / \mathrm{z}=239$ and 240 might be attributed to trace amount of plutonium contamination in the laboratory environment and chemical reagents, instrumental memory of plutonium as well as the contribution of hydride of uranium in the blanks. The analytical results of plutonium in the samples were lways corrected by subtraction of the procedure blanks prepared and measured in the same batch as the samples.

Using the measured sensitivity of $340 \mathrm{cps} / \mathrm{ppt}$ for plutonium isotopes by the developed ICPMS/MS method and the chemical yield of plutonium (average 85\%) in the entire separation procedure, the limit of detection of the method can be calculated as 3 times of standard deviation of the signal intensity of the procedure blanks to be $0.93 \mathrm{fg}$ for ${ }^{239} \mathrm{Pu}$ and 0.62 fg for ${ }^{240} \mathrm{Pu}$ (for 3.0 $\mathrm{mL}$ sample solution), which are corresponding to $2.1 \mu \mathrm{Bq}$ for ${ }^{239} \mathrm{Pu}$ and $5.2 \mu \mathrm{Bq}$ for ${ }^{240} \mathrm{Pu}$. The limit of detection was further improved by employing a high efficiency introduction system of APEX $\Omega$ for about 5 times to 0.2 fg for ${ }^{239} \mathrm{Pu}$ and 0.1 fg for ${ }^{240} \mathrm{Pu}$, because the counting efficiency of plutonium was increased by a factor of $8\left(2650 \mathrm{cps} / \mathrm{ppt}{ }^{239} \mathrm{Pu}\right)$ and uranium hydrides was further supressed by a factor of 2 . Although the count rates of ${ }^{239} \mathrm{Pu}^{+}(0.65 \pm 0.15 \mathrm{cps})$ and ${ }^{240} \mathrm{Pu}^{+}(0.25$ $\pm 0.08 \mathrm{cps})$ in the procedure blank also enhanced, but the variations/relative standard deviations of signal intensities of blanks were improved.

\section{Application of the developed method for determination of ${ }^{239} \mathrm{Pu}$ and ${ }^{240} \mathrm{Pu}$ in environmental}

samples. Two deep $(25-30 \mathrm{~cm})$ and four surface $(0-5 \mathrm{~cm})$ soil samples collected from the 
background areas at sites without visible disturbance in China were analyzed using the developed method for ${ }^{239} \mathrm{Pu}$ and ${ }^{240} \mathrm{Pu}$. The analytical results (Table 4) show a big variation of concentrations of ${ }^{239} \mathrm{Pu}$ and ${ }^{240} \mathrm{Pu}$ in the surface soil ranging from 0.07 to $0.13 \mathrm{mBq} / \mathrm{g}$ for ${ }^{239} \mathrm{Pu}$ and $0.048-0.087$ $\mathrm{mBq} / \mathrm{g}$ for ${ }^{240} \mathrm{Pu}$, corresponding to a range of $0.12-0.22 \mathrm{mBq} / \mathrm{g}$ for ${ }^{239,240} \mathrm{Pu}$, which fall into the reported range of ${ }^{239,240} \mathrm{Pu}$ concentrations in the surface soil in the background areas in China $(0.07$ $0.85 \mathrm{mBq} / \mathrm{g}$ for $\left.{ }^{239,240} \mathrm{Pu}\right){ }^{35,36}$. The concentrations of ${ }^{239} \mathrm{Pu}$ and ${ }^{240} \mathrm{Pu}$ in the deep soil are more than 50 times lower than that determined in the surface soil in the same site. Exponentially decreased plutonium concentrations with the depth in soil core and much low concentrations of ${ }^{239,240} \mathrm{Pu}$ $(<0.01 \mathrm{mBq} / \mathrm{g})$ in the deep soil $(>25 \mathrm{~cm})$ in undisturbed soil profiles have reported in many locations $19,37,38$. This is attributed to the high association of fallout plutonium with organic substance and minerals, causing a low vertical migration of fallout plutonium in soil core ${ }^{39}$. The measured ${ }^{240} \mathrm{Pu} /{ }^{239} \mathrm{Pu}$ atomic ratios in these samples are around 0.18 , which agree well with the reported ratio of the global fallout plutonium ${ }^{3}$, indicating the dominant global fallout source of plutonium in these samples.

For accurate determination of low-level plutonium isotopes in deep soil samples, $30 \mathrm{~g}$ soil sample was analyzed. In this case, a large amount of uranium presents in the samples. The uranium concentrations in the deep soil samples were measured to be 3.0-3.5 $\mu \mathrm{g} / \mathrm{g}$, meaning more than 90 $\mu \mathrm{g}$ uranium presents in these samples with ultra-low level plutonium $\left((1-5) \times 10^{-3} \mathrm{mBq} / \mathrm{g}{ }^{239} \mathrm{Pu}\right.$, corresponding to $0.4-2 \mathrm{fg} / \mathrm{g}{ }^{239} \mathrm{Pu}$ ), with ${ }^{238} \mathrm{U} /{ }^{239} \mathrm{Pu}$ atomic ratios up to $10^{10}$. This demonstrates that the developed method enables to accurately determine as low as $1 \mu \mathrm{Bq}{ }^{239} \mathrm{Pu}$ and ${ }^{240} \mathrm{Pu}$ in such a $10^{10}$ folds higher uranium samples. 


\section{Conclusions}

An analytical method based on chemical separation and ICP-MS measurement was developed for accurate determination of ultra-low level plutonium isotopes in high uranium samples. The most critical interference of uranium to the measurement of ${ }^{239} \mathrm{Pu}$ and ${ }^{240} \mathrm{Pu}$ was effectively eliminated by using an ICP-MS/MS instrument and $1.2 \mathrm{~mL} / \mathrm{min} \mathrm{CO}_{2}-8.0 \mathrm{~mL} / \mathrm{min}$ helium as reaction gas. The interference of uranium to the measurement of ${ }^{239} \mathrm{Pu}\left({ }^{238} \mathrm{U}^{1} \mathrm{H}^{+} / 238 \mathrm{U}^{+}\right.$ratio) was reduced to $10^{-8}$, which is more than 2 orders of magnitude better than the previously reported ICP-MS methods. Combined with the chemical separation using extraction chromatography with TEVA resin, an overall elimination efficiency of uranium interference reaches $10^{12}$, making it enable to accurate determine femtogram level plutonium isotopes in samples containing milligram uranium. Uranium hydride interference was efficiently eliminated by reaction with $\mathrm{CO}_{2}$ in the DRC to completely convert $\mathrm{U}^{+}$and $\mathrm{UH}^{+}$to $\mathrm{UO}^{+}$and $\mathrm{UO}_{2}{ }^{+}$ions. While, plutonium reacts only partly with $\mathrm{CO}_{2}$, enable it to be measured as $\mathrm{Pu}^{+}$ion. The abundance sensitivity (tailing of ${ }^{238} \mathrm{U}$ at $\mathrm{m} / \mathrm{z}=239$ ) was improved to $<2 \times 10^{-11}$, which is $10^{6}$ times better than the conventional ICP-MS method. The measurement sensitivity for plutonium isotopes was improved by a factor 3 by collision focusing using high flow rate of helium into the DRC. Analysis of spiked samples demonstrated the reliability of the developed method for accurate determination of femtogram of ${ }^{239} \mathrm{Pu}$ in high uranium samples with $\mathrm{U} / \mathrm{Pu}$ atomic ratio up to $10^{12}$. The developed method has been verified by the analysis of certified reference materials, and successfully applied for the determination of environmental samples with femtogram level plutonium isotopes. 


\begin{abstract}
ASSOCIATED CONTENT
Supporting Information

The Supporting Information, which is available free of charge on the ACS Publications website. A detailed analytical method, 6 tables and 4 figures are presented.
\end{abstract}

\begin{abstract}
AUTHOR INFORMATION
Corresponding Author

* Xiaolin Hou, Phone: +45-21325129, E-mail: xiho@dtu.dk.

Notes

The authors declare no competing financial interest.

Author Contributions

The manuscript was written through contributions of all authors. XH designed the experiment, drafted and revised the manuscript, WZ and YW implemented the experiment, and WZ also participated in draft preparation and prepared all figures. All authors have given approval to the final version of the manuscript.
\end{abstract}

\title{
ACKNOWLEDGEMENTS
}

This work was supported by the National Natural Science Foundation of China (11605206, 11875261, 41603125 and 91643206), the Ministry of Science and Technology of China (2015FY110800) and Chinese Academy of Sciences (132B61KYSB20180003) and National Research Program for Key Issues in Air Pollution Control (DQGG0105-02). 


\section{Reference}

(1) UNSCEAR, Sources and effects of ionizing radiation.UNSCEAR 1993 Report to the General Assembly, with Scientific Annexes; United Nations Scientific Committee on the Effects of Atomic Radiation: United Nations, New York, 1993.

(2) Qiao, J.; Hou, X.; Miró, M.; Roos, P. Determination of plutonium isotopes in waters and environmental solids: A review. Anal. Chim. Acta 2009, 652, 66-84.

(3) Kelley, J. M.; Bond, L. A.; Beasley, T. M. Global distribution of Pu isotopes and ${ }^{237}$ Np. Sci. Total Environ. 1999, 237-238, 483-500.

(4) Eriksson, M.; Lindahl, P.; Roos, P.; Dahlgaard, H.; Holm, E. U, Pu, and Am Nuclear Signatures of the Thule Hydrogen Bomb Debris. Environ. Sci. Technol. 2008, 42, 4717-4722.

(5) Wolf, S. F.; Bates, J. K.; Buck, E. C.; Dietz, N. L.; Fortner, J. A.; Brown, N. R. Physical and Chemical Characterization of Actinides in Soil from Johnston Atoll. Environ. Sci. Technol. 1997, $31,467-471$.

(6) Zheng, J.; Tagami, K.; Uchida, S. Release of Plutonium Isotopes into the Environment from the Fukushima Daiichi Nuclear Power Plant Accident: What Is Known and What Needs to Be Known. Environ. Sci. Technol. 2013, 47, 9584-9595.

(7) Warneke, T.; Croudace, I. W.; Warwick, P. E.; Taylor, R. N. A new ground-level fallout record of uranium and plutonium isotopes for northern temperate latitudes. Earth Planet. Sci. Lett. 2002, 203, 1047-1057.

(8) Boulyga, S. F.; Becker, J. S. Isotope analysis of uranium and plutonium using ICP-MS and estimation of burn-up of spent uranium in contaminated environmental samples. J. Anal. At. Spectrom. 2002, 17, 1143-1147.

(9) Wang, J.; Baskaran, M.; Hou, X.; Du, J.; Zhang, J. Historical changes in ${ }^{239} \mathrm{Pu}$ and ${ }^{240} \mathrm{Pu}$ sources 
in sedimentary records in the East China Sea: Implications for provenance and transportation. Earth Planet. Sci. Lett. 2017, 466, 32-42.

(10) Betti, M.; Tamborini, G.; Koch, L. Use of Secondary Ion Mass Spectrometry in Nuclear Forensic Analysis for the Characterization of Plutonium and Highly Enriched Uranium Particles. Anal. Chem. 1999, 71, 2616-2622.

(11) Hou, X.; Roos, P. Critical comparison of radiometric and mass spectrometric methods for the determination of radionuclides in environmental, biological and nuclear waste samples. Anal. Chim. Acta 2008, 608, 105-139.

(12) Grate, J. W.; O’Hara, M. J.; Farawila, A. F.; Douglas, M.; Haney, M. M.; Petersen, S. L.; Maiti, T. C.; Aardahl, C. L. Extraction Chromatographic Methods in the Sample Preparation Sequence for Thermal Ionization Mass Spectrometric Analysis of Plutonium Isotopes. Anal. Chem. 2011, $83,9086-9091$.

(13) Fifield, L. K. Accelerator mass spectrometry of the actinides. Quat. Geochronol. 2008, 3, 276-290.

(14) Xing, S.; Zhang, W.; Qiao, J.; Hou, X. Determination of ultra-low level plutonium isotopes $\left({ }^{239} \mathrm{Pu},{ }^{240} \mathrm{Pu}\right)$ in environmental samples with high uranium. Talanta 2018, 187, 357-364.

(15) Qiao, J.; Hou, X.; Roos, P.; Miró, M. Rapid Determination of Plutonium Isotopes in Environmental Samples Using Sequential Injection Extraction Chromatography and Detection by Inductively Coupled Plasma Mass Spectrometry. Anal. Chim. 2009, 81, 8185-8192.

(16) Kierepko, R.; Mietelski, J. W.; Ustrnul, Z.; Anczkiewicz, R.; Wershofen, H.; Holgye, Z.; Kapała, J.; Isajenko, K. Plutonium isotopes in the atmosphere of Central Europe: Isotopic composition and time evolution vs. circulation factors. Sci. Total Environ. 2016, 569-570, 937947. 
(17) Hirose, K.; Povinec, P. P. Sources of plutonium in the atmosphere and stratospheretroposphere mixing. Sci. Rep. 2015, 5, 15707.

(18) Wang, Z.; Zheng, J.; Ni, Y.; Men, W.; Tagami, K.; Uchida, S. High performance method for rapid determination of $\mathrm{Pu}$ isotopes in soil and sediment samples by sector field inductively coupled plasma mass spectrometry. Anal. Chem. 2017, 89, 2221-2226.

(19) Xu, Y.; Qiao, J.; Pan, S.; Hou, X.; Roos, P.; Cao, L. Plutonium as a tracer for soil erosion assessment in northeast China. Sci. Total Environ. 2015, 511, 176-185.

(20) Xu, Y.; Qiao, J.; Hou, X.; Pan, S.; Roos, P. Determination of plutonium isotopes $\left({ }^{238} \mathrm{Pu},{ }^{239} \mathrm{Pu}\right.$, ${ }^{240} \mathrm{Pu},{ }^{241} \mathrm{Pu}$ ) in environmental samples using radiochemical separation combined with radiometric and mass spectrometric measurements. Talanta 2014, 119, 590-595.

(21) Wu, J.; Zheng, J.; Dai, M.; Huh, C.-A.; Chen, W.; Tagami, K.; Uchida, S. Isotopic Composition and Distribution of Plutonium in Northern South China Sea Sediments Revealed Continuous Release and Transport of Pu from the Marshall Islands. Environ. Sci. Technol. 2014, $48,3136-3144$.

(22) Yamada, M.; Zheng, J. ${ }^{239} \mathrm{Pu}$ and ${ }^{240} \mathrm{Pu}$ inventories and ${ }^{240} \mathrm{Pu} /{ }^{239} \mathrm{Pu}$ atom ratios in the equatorial Pacific Ocean water column. Sci. Total Environ. 2012, 430, 20-27.

(23) Baxter, M. S.; Fowler, S. W.; Povinec, P. P. Observations on plutonium in the oceans. Appl. Radiat. Isot. 1995, 46, 1213-1223.

(24) Pointurier, F.; Hémet, P.; Hubert, A. Assessment of plutonium measurement in the femtogram range by ICP-MS; correction from interfering polyatomic species. J. Anal. At. Spectrom. 2008, $23,94-102$.

(25) Varga, Z.; Surányi, G.; Vajda, N.; Stefánka, Z. Determination of plutonium and americium in environmental samples by inductively coupled plasma sector field mass spectrometry and alpha 
spectrometry. Microchem. J. 2007, 85, 39-45.

(26) Warwick, P. E.; Croudace, I. W.; Oh, J. S. Radiochemical determination of ${ }^{241} \mathrm{Am}$ and $\mathrm{Pu}(\alpha)$ in environmental materials. Anal. Chem. 2001, 73, 3410-3416.

(27) Childs, D. A.; Hill, J. G. The use of carbon dioxide as the reaction cell gas for the separation of uranium and plutonium in quadrupole inductively coupled plasma mass spectrometry (ICPMS) for nuclear forensic samples. J. Radioanal. Ncl. Chem. 2018, 318, 139-148.

(28) Gourgiotis, A.; Granet, M.; Isnard, H.; Nonell, A.; Gautier, C.; Stadelmann, G.; Aubert, M.; Durand, D.; Legand, S.; Chartier, F. Simultaneous uranium/plutonium separation and direct isotope ratio measurements by using $\mathrm{CO}_{2}$ as the gas in a collision/reaction cell based MCICPMS. J Anal. Atom. Spectrom. 2010, 25, 1939-1945.

(29) Vais, V.; Li, C.; Cornett, J. Separation of plutonium from uranium using reactive chemistry in a bandpass reaction cell of an inductively coupled plasma mass spectrometer. Anal. Bioanal. Chem. 2004, 380, 235-239.

(30) Tanner, S. D.; Li, C.; Vais, V.; Baranov, V. I.; Bandura, D. R. Chemical Resolution of Pu from $\mathrm{U}^{+}$and $\mathrm{Am}^{+}$Using a Band-Pass Reaction Cell Inductively Coupled Plasma Mass Spectrometer. Anal. Chem. 2004, 76, 3042-3048.

(31) Amr, M. A.; Helal, A.-F. I.; Al-Kinani, A. T.; Balakrishnan, P. Ultra-trace determination of ${ }^{90} \mathrm{Sr},{ }^{137} \mathrm{Cs},{ }^{238} \mathrm{Pu},{ }^{239} \mathrm{Pu}$, and ${ }^{240} \mathrm{Pu}$ by triple quadruple collision/reaction cell-ICP-MS/MS: Establishing a baseline for global fallout in Qatar soil and sediments. J. Environ. Radioact. 2016, $153,73-87$.

(32) Santos, M.; Marçalo, J.; Matos, A. P. d.; Gibson, J. K.; Haire, R. G. Gas-Phase Oxidation Reactions of Neptunium and Plutonium Ions Investigated via Fourier Transform Ion Cyclotron Resonance Mass Spectrometry. J. Phys. Chem. A 2002, 106, 7190-7194. 
(33) Qiao, J.; Hou, X.; Roos, P.; Miró, M. High-Throughput Sequential Injection Method for Simultaneous Determination of Plutonium and Neptunium in Environmental Solids Using Macroporous Anion-Exchange Chromatography, Followed by Inductively Coupled Plasma Mass Spectrometric Detection. Anal. Chem. 2011, 83, 374-381.

(34) Bojanowski, R.; Radecki, Z.; Campbell, M. J.; Burns, K. I.; A.Trinkl, Report on the intercomparison run for the determination of radionuclides in soils. IAEA-326 and IAEA-327: International Atomic Energy Agency, 2001.

(35) Ni, Y.; Wang, Z.; Guo, Q.; Zheng, J.; Li, S.; Lin, J.; Tan, Z.; Huang, W. Distinctive distributions and migrations of ${ }^{239+240} \mathrm{Pu}$ and ${ }^{241} \mathrm{Am}$ in Chinese forest, grassland and desert soils. Chemosphere 2018, 212, 1002-1009.

(36) Xing, S. Trace application of long-lived radionuclides ${ }^{239,240} \mathrm{Pu}$ and ${ }^{129} \mathrm{I}$ in the environment. D, The University of Chinese Academy of Sciences. (in Chinese)2015.

(37) Bu, W.; Zheng, J.; Guo, Q.; Uchida, S. Vertical distribution and migration of global fallout Pu in forest soils in southwestern China. J. Environ. Radioact. 2014, 136, 174-180.

(38) Xu, Y.; Qiao, J.; Hou, X.; Pan, S. Plutonium in soils from northeast China and its potential application for evaluation of soil erosion. Sci. Rep. 2013, 3, 1-8.

(39) Qiao, J.; Hansen, V.; Hou, X.; Aldahan, A.; Possnert, G. Speciation analysis of ${ }^{129}$ I, ${ }^{137}$ Cs, ${ }^{232} \mathrm{Th},{ }^{238} \mathrm{U},{ }^{239} \mathrm{Pu}$ and ${ }^{240} \mathrm{Pu}$ in environmental soil and sediment. Appl. Radiat. Isot. 2012, 70, $1698-1708$.

(40) Chiappini, R.; Taillade, J. M.; Brébion, S. Development of a high-sensitivity inductively coupled plasma mass spectrometer for actinide measurement in the femtogram range. J. Anal. Atom. Spectrom. 1996, 11, 497-503.

(41) Crain, J. S.; Alvarado, J. Hydride interference on the determination of minor actinide isotopes 
by inductively coupled plasma mass spectrometry. J. Anal. Atom. Spectrom. 1994, 9, 1223-1227.

(42) Stürup, S.; Dahlgaard, H.; Nielsen, S. C. High resolution inductively coupled plasma mass spectrometry for the trace determination of plutonium isotopes and isotope ratios in environmental samples. J. Anal. Atom. Spectrom. 1998, 13, 1321-1326.

(43) Kim, C. S.; Kim, C. K.; Lee, J. I.; Lee, K. J. Rapid determination of Pu isotopes and atom ratios in small amounts of environmental samples by an on-line sample pre-treatment system and isotope dilution high resolution inductively coupled plasma mass spectrometry. J. Anal. At. Spectrom. 2000, 15, 247-255.

(44) Lindahl, P.; Keith-Roach, M.; Worsfold, P.; Choi, M.-S.; Shin, H.-S.; Lee, S.-H. Ultra-trace determination of plutonium in marine samples using multi-collector inductively coupled plasma mass spectrometry. Anal. Chim. Acta 2010, 671, 61-69.

(45) Zheng, J.; Yamada, M. Inductively coupled plasma-sector field mass spectrometry with a high-efficiency sample introduction system for the determination of $\mathrm{Pu}$ isotopes in settling particles at femtogram levels. Talanta 2006, 69, 1246-1253.

(46) Boulyga, S. F.; Heumann, K. G. Determination of extremely low ${ }^{236} U /{ }^{238} U$ isotope ratios in environmental samples by sector-field inductively coupled plasma mass spectrometry using high-efficiency sample introduction. J. Environ. Radioact. 2006, 88, 1-10. 
Table 1 Results of abundance sensitivity of ${ }^{238} \mathrm{U}$ at $\mathrm{m} / \mathrm{z}=237$ in different mode of ICP-MS

\begin{tabular}{ccc}
\hline Mode \# & ICP-MS (single quadrupole) & ICP-MS/MS (tandem quadrupoles) \\
\hline No Gas & $2.36 \times 10^{-4}$ & $3.47 \times 10^{-8}$ \\
$\mathrm{He}$ & $8.08 \times 10^{-5}$ & $8.19 \times 10^{-9}$ \\
$\mathrm{NH}_{3}-\mathrm{He}$ & $6.88 \times 10^{-6}$ & $5.50 \times 10^{-10}$ \\
$\mathrm{O}_{2}$ & $1.76 \times 10^{-5}$ & $2.29 \times 10^{-11}$ \\
$\mathrm{CO}_{2}-\mathrm{He}$ & $4.14 \times 10^{-7}$ & $<2 \times 10^{-11}$
\end{tabular}

\# No gas: no collision/reaction gas was applied; He: $8.0 \mathrm{~mL} / \mathrm{min}$ helium as collision gas; $\mathrm{NH}_{3} / \mathrm{He}: 1.2 \mathrm{~mL} / \mathrm{min} \mathrm{NH} \mathrm{NH}_{3}-8 \mathrm{~mL} / \mathrm{min} \mathrm{He} ; \mathrm{O}_{2}: 2.0 \mathrm{~mL} / \mathrm{min} \mathrm{O}_{2} ; \mathrm{CO}_{2}-\mathrm{He}: 1.2 \mathrm{~mL} / \mathrm{min}-8.0$ $\mathrm{mL} / \mathrm{min} \mathrm{He}$. 
Table 2 Efficiency of uranium hydrides elimination $\left({ }^{238} \mathrm{UH}^{+} / 238 \mathrm{U}^{+}\right.$and ${ }^{238} \mathrm{UH}_{2}^{+} / 238 \mathrm{U}^{+}$ratios $)$and ${ }^{239} \mathrm{Pu}$ sensitivity in ICP-MS/MS measurement with the different reaction gas and comparison with the reported data of other methods

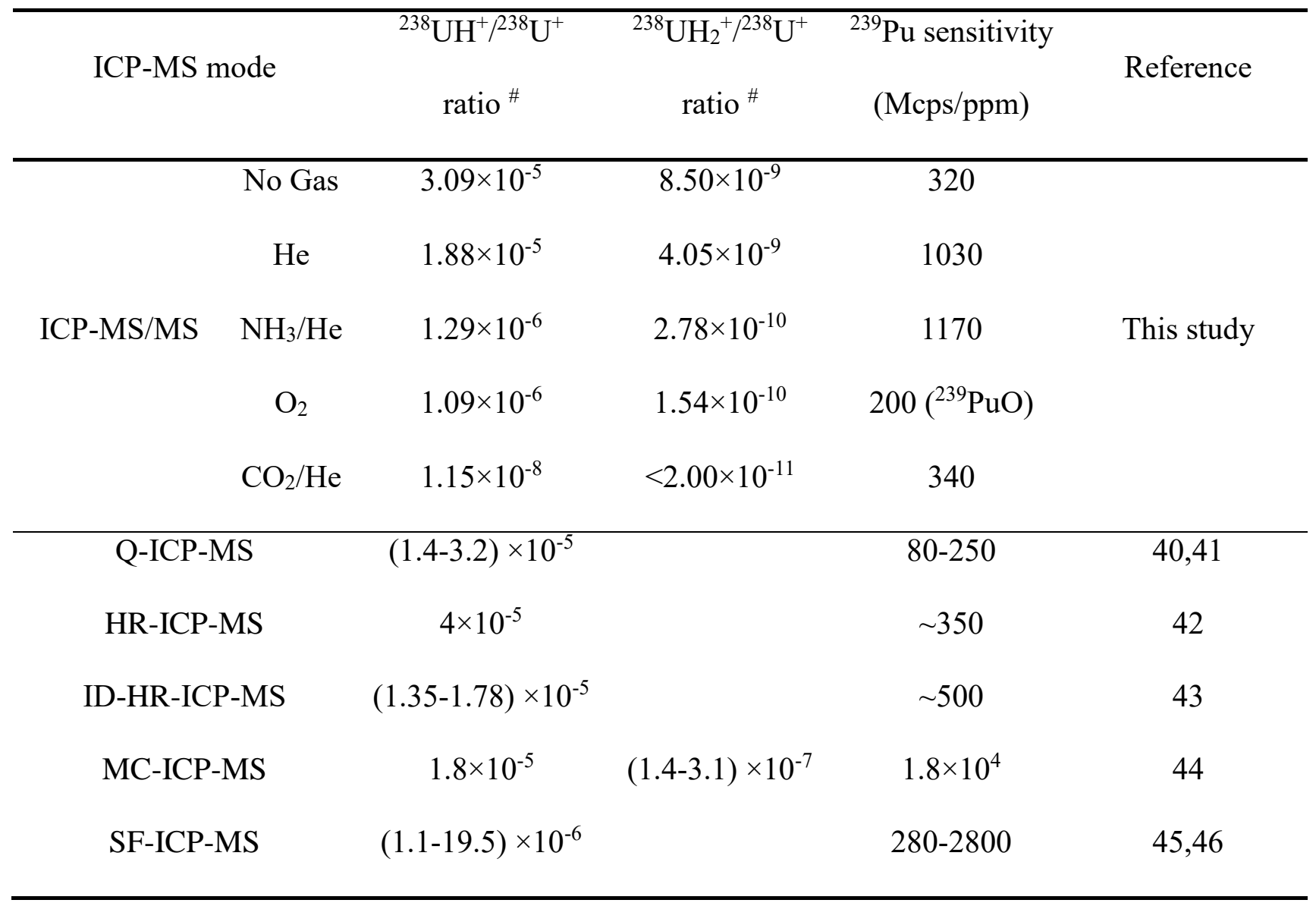

\# The ratios were estimated using the measured signal intensities at $\mathrm{m} / \mathrm{z}=239$ and 240 as the contribution of ${ }^{238} \mathrm{U}^{1} \mathrm{H}^{+}$and ${ }^{238} \mathrm{U}^{1} \mathrm{H}_{2}{ }^{+}$ions in comparison with the intensity of ${ }^{238} \mathrm{U}^{+}$in the corresponding condition; For modes of no gas and helium as reaction gas, the intensity of ${ }^{238} \mathrm{U}^{+}$ signal was used; for $\mathrm{CO}_{2}-\mathrm{He}$ and $\mathrm{NH}_{3}-\mathrm{He}$ modes, the intensity of ${ }^{238} \mathrm{U}^{+}$signal at $8 \mathrm{ml} / \mathrm{min} \mathrm{He}$ as collision gas, and for $\mathrm{O}_{2}$ mode, the intensity of ${ }^{238} \mathrm{U}^{+}$signal of no gas mode was used. 
Table 3 Determination of ${ }^{239} \mathrm{Pu}$ in simulated high uranium solution using ICP-MS/MS with different reaction gasses

\begin{tabular}{|c|c|c|c|c|c|c|c|c|c|c|}
\hline \multicolumn{3}{|c|}{ Sample solution } & \multicolumn{8}{|c|}{ Measurement results of ${ }^{239} \mathrm{Pu}$} \\
\hline \multirow{3}{*}{$\begin{array}{c}\mathrm{U} \text { conc. } \\
10^{-9} \mathrm{~g} / \mathrm{mL}\end{array}$} & \multirow{3}{*}{$\begin{array}{l}{ }^{239} \mathrm{Pu} \text { conc. } \\
10^{-15} \mathrm{~g} / \mathrm{mL}\end{array}$} & \multirow{3}{*}{$\begin{array}{l}{ }^{239} \mathrm{Pu} /{ }^{238} \mathrm{U} \\
\text { atomic ratio }\end{array}$} & \multicolumn{2}{|c|}{ No gas } & \multicolumn{2}{|c|}{ He gas $^{1)}$} & \multicolumn{2}{|c|}{$\mathrm{NH}_{3}-\mathrm{He}$ gas $^{2)}$} & \multicolumn{2}{|c|}{$\mathrm{CO}_{2}-\mathrm{He}$ gas $^{3)}$} \\
\hline & & & ${ }^{239} \mathrm{Pu}$ conc. & Division & ${ }^{239} \mathrm{Pu}$ conc. & Division & ${ }^{239} \mathrm{Pu}$ conc. & Division & ${ }^{239} \mathrm{Pu}$ conc. & Division \\
\hline & & & $10^{-15} \mathrm{~g} / \mathrm{mL}$ & & $10^{-15} \mathrm{~g} / \mathrm{mL}$ & $\%$ & $10^{-15} \mathrm{~g} / \mathrm{mL}$ & $\%$ & $10^{-15} \mathrm{~g} / \mathrm{mL}$ & $\%$ \\
\hline 0.010 & 10.1 & $1.01 \times 10^{-3}$ & $10.0 \pm 0.6$ & $-1.0 \%$ & $10.8 \pm 0.8$ & $6.9 \%$ & & & & \\
\hline 0.10 & 10.1 & $1.01 \times 10^{-4}$ & $11.7 \pm 0.7$ & $15.8 \%$ & $10.7 \pm 0.9$ & $5.9 \%$ & $9.92 \pm 0.71$ & $-2.0 \%$ & & \\
\hline 1.00 & 10.1 & $1.01 \times 10^{-5}$ & $47.1 \pm 1.4$ & $370 \%$ & $22.3 \pm 1.6$ & $120 \%$ & $11.4 \pm 0.7$ & $13.9 \%$ & $10.0 \pm 0.8$ & $-1.0 \%$ \\
\hline 10.0 & 10.1 & $1.01 \times 10^{-6}$ & & & & & $22.3 \pm 1.6$ & $121 \%$ & $10.4 \pm 0.9$ & $3.0 \%$ \\
\hline 100.0 & 10.1 & $1.01 \times 10^{-7}$ & & & & & & & $11.1 \pm 0.8$ & $11.9 \%$ \\
\hline 988.0 & 10.1 & $1.01 \times 10^{-8}$ & & & & & & & $24.4 \pm 1.6$ & $140 \%$ \\
\hline
\end{tabular}

1) $8.0 \mathrm{~mL} / \mathrm{min}$ helium gas as reaction gas; 2) $1.2 \mathrm{~mL} / \mathrm{min} \mathrm{NH}_{3}-8.0 \mathrm{~mL} / \mathrm{min}$ helium; 3) $1.2 \mathrm{~mL} / \mathrm{min} \mathrm{CO}_{2}-8.0 \mathrm{~mL} / \mathrm{min} \mathrm{He}$. 
Table 4 Determination of certified reference materials (IAEA-327 and IAEA-385) and environmental soil samples using ICP-MS/MS under tandem- $\mathrm{CO}_{2} / \mathrm{He}$ mode with anion exchange chromatography

\begin{tabular}{|c|c|c|c|c|c|c|c|c|c|}
\hline $\begin{array}{l}\text { Sample } \\
\text { Code }\end{array}$ & $\begin{array}{c}\text { Sampling } \\
\text { location/depth }\end{array}$ & $\begin{array}{l}\text { Sample } \\
\text { mass, g }\end{array}$ & $\begin{array}{c}\text { Chemical } \\
\text { yield }\end{array}$ & $\begin{array}{c}{ }^{239} \mathrm{Pu} \text { counts } \\
(\mathrm{cps})\end{array}$ & $\begin{array}{c}{ }^{240} \mathrm{Pu} \text { counts } \\
(\mathrm{cps})\end{array}$ & $\begin{array}{c}{ }^{239} \mathrm{Pu} \\
\text { concentration } \\
(\mathrm{mBq} / \mathrm{g})\end{array}$ & $\begin{array}{c}{ }^{240} \mathrm{Pu} \text { concentration } \\
(\mathrm{mBq} / \mathrm{g})\end{array}$ & $\begin{array}{l}{ }^{240} \mathrm{Pu} /{ }^{239} \mathrm{Pu} \\
\text { atomic ratio }\end{array}$ & Reference \\
\hline $3 \% \mathrm{HNO}_{3}$ & Instrument blank & & & $0.072 \pm 0.023$ & $0.021 \pm 0.012$ & & & & \\
\hline Blank & Procedure blank & & & $0.153 \pm 0.033$ & $0.042 \pm 0.023$ & & & & \\
\hline IAEA-327 & Certified reference & $1.9-2.0$ & $85-90 \%$ & $23.7 \pm 0.9$ & $4.54 \pm 0.21$ & $0.333 \pm 0.019$ & $0.232 \pm 0.017$ & $0.191 \pm 0.018$ & This study \\
\hline soil & material & & & & & $0.35 \pm 0.02$ & $0.25 \pm 0.02$ & $0.19 \pm 0.02$ & 34 \\
\hline IAEA-385 & Certified reference & $1.7-1.8$ & $85-90 \%$ & $92.6 \pm 2.5$ & $16.6 \pm 0.5$ & $\begin{array}{c}1.77 \pm 0.09 \\
1.92\end{array}$ & $\begin{array}{c}1.13 \pm 0.08 \\
1.18\end{array}$ & $0.175 \pm 0.015$ & $\begin{array}{c}\text { This study } \\
\text { Reference value }\end{array}$ \\
\hline & materials & & & & & $1.79 \pm 0.28$ & $1.15 \pm 0.14$ & $0.174 \pm 0.032$ & 14,33 \\
\hline GDHY-1 & $\begin{array}{l}\text { Guangdong } \\
(25-30 \mathrm{~cm})\end{array}$ & $20.0-20.5$ & $85-90 \%$ & $1.10 \pm 0.11$ & $0.193 \pm 0.022$ & $(1.30 \pm 0.22) \times 10^{-3}$ & $(0.852 \pm 0.145) \times 10^{-3}$ & $0.178 \pm 0.043$ & This study \\
\hline GDHY-2 & Guandong $(0-5 \mathrm{~cm})$ & $2.0-2.1$ & $85-90 \%$ & $5.75 \pm 0.23$ & $0.923 \pm 0.111$ & $0.074 \pm 0.005$ & $0.048 \pm 0.007$ & $0.177 \pm 0.028$ & This study \\
\hline NMTL & $\begin{array}{l}\text { Inner Mongolia } \\
\qquad(25-30 \mathrm{~cm})\end{array}$ & $10.0-10.1$ & $82-87 \%$ & $2.05 \pm 0.12$ & $0.172 \pm 0.018$ & $(5.10 \pm 0.71) \times 10^{-3}$ & $(3.42 \pm 0.52) \times 10^{-3}$ & $0.183 \pm 0.038$ & This study \\
\hline SXXA & Shaanxi, $(0-5 \mathrm{~cm})$ & $3.5-3.6$ & $82-87 \%$ & $11.4 \pm 0.5$ & $2.17 \pm 0.21$ & $0.090 \pm 0.009$ & $0.061 \pm 0.009$ & $0.184 \pm 0.033$ & This study \\
\hline FJND & Fujian, $(0-5 \mathrm{~cm})$ & $4.0-4.1$ & $82-87 \%$ & $15.7 \pm 0.8$ & $2.35 \pm 0.25$ & $0.109 \pm 0.009$ & $0.075 \pm 0.012$ & $0.187 \pm 0.034$ & This study \\
\hline ZJWZ & Zhejiang $(0-5 \mathrm{~cm})$ & $2.0-2.1$ & $85-90 \%$ & $10.3 \pm 0.7$ & $1.87 \pm 0.19$ & $0.132 \pm 0.018$ & $0.087 \pm 0.014$ & $0.180 \pm 0.038$ & This study \\
\hline
\end{tabular}

Note: the results presented here are average of three replicates of each certified reference material, and the uncertainties are estimated from the all analytical process with coverage factor of $\mathrm{k}=1$ 


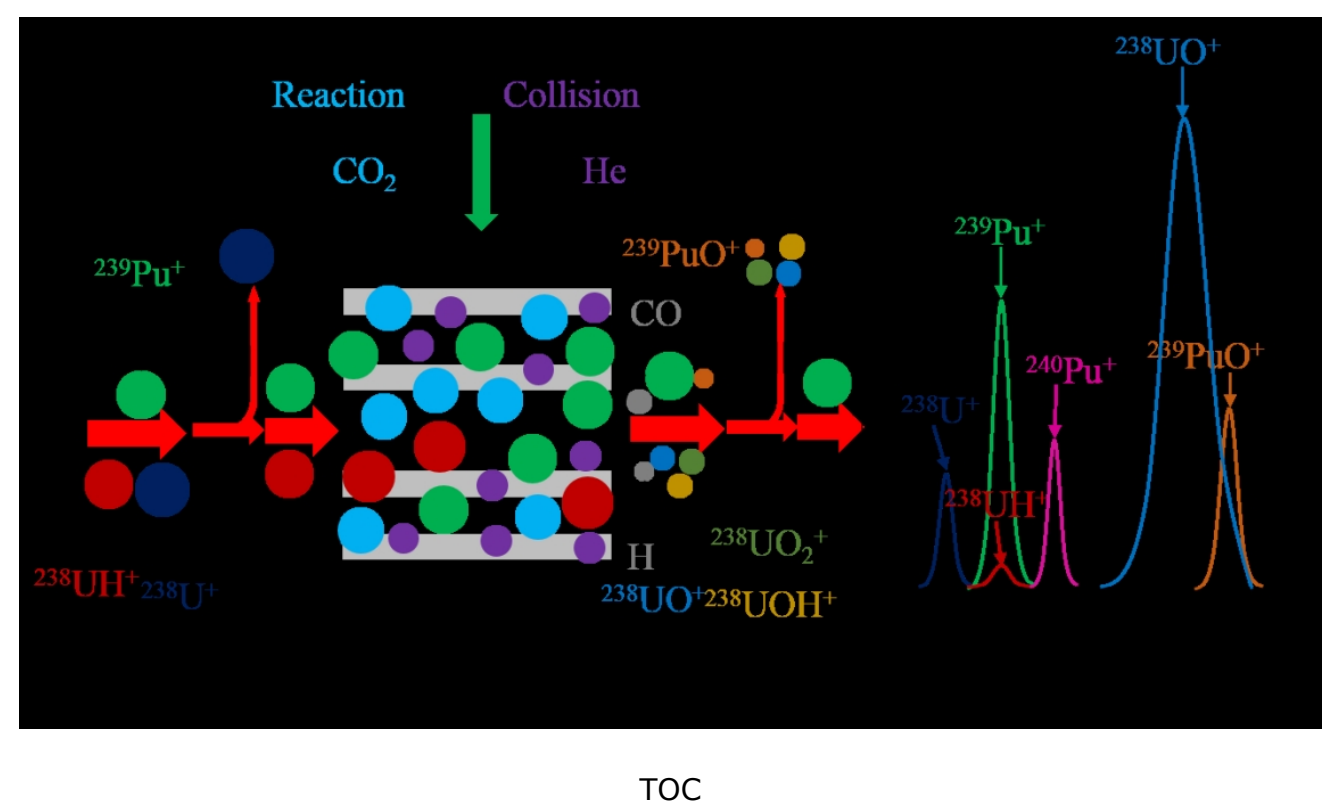

$222 \times 121 \mathrm{~mm}(150 \times 150 \mathrm{DPI})$ 


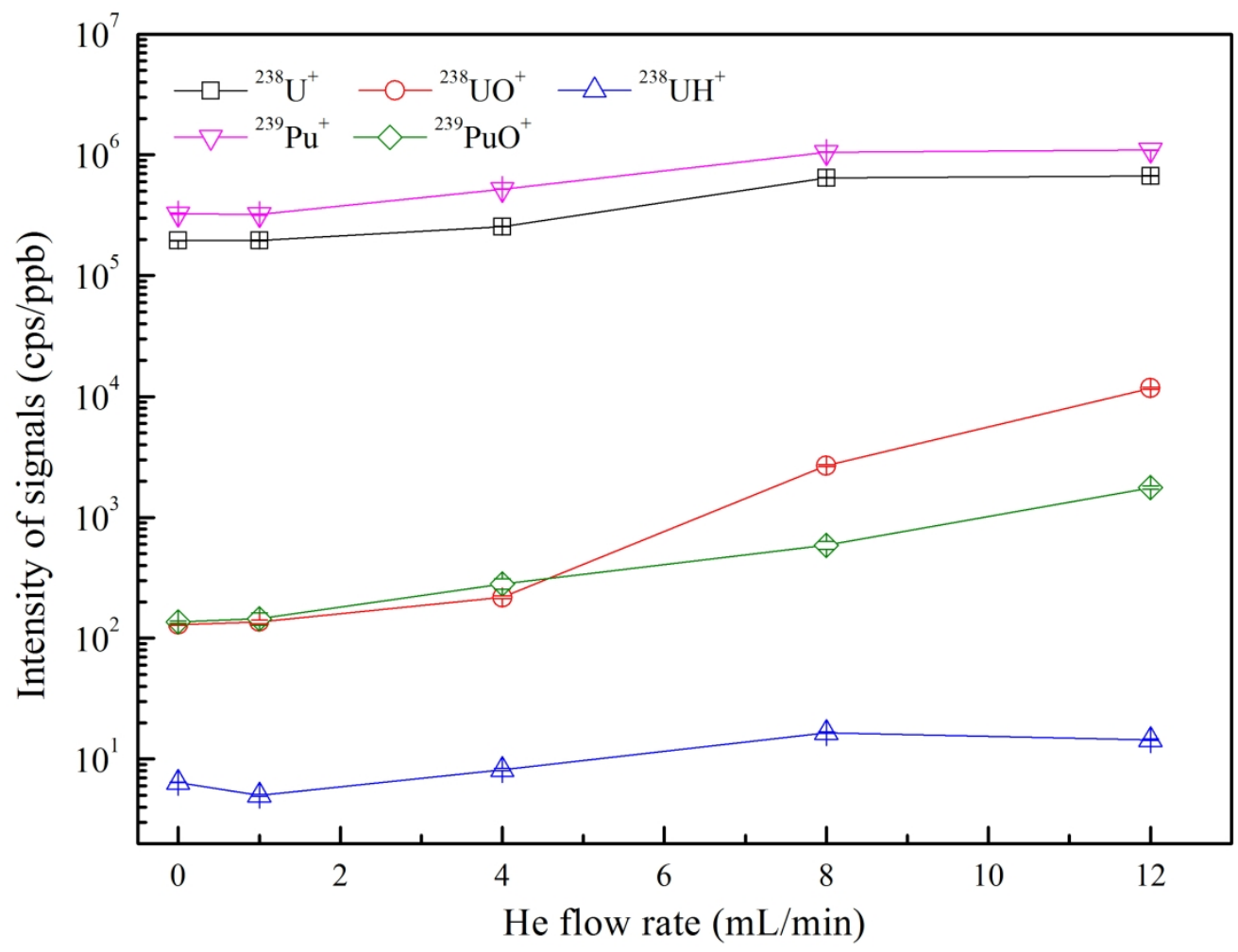

Figure 1 Variation of the intensities of $\mathrm{Pu}+, \mathrm{PuO}+, \mathrm{U}+, \mathrm{UH}+, \mathrm{UO}+$ ion with the flow rate of hellium injected to the DRC. For Pu+ and PuO+, the $\mathrm{m} / \mathrm{z}=239$ was selected in the Q1 (first quadrupole) and $\mathrm{m} / \mathrm{z}=239$ and 255 in the Q2 (second quadrupole), respectively; for $\mathrm{U}+$ and $\mathrm{UO}+$, the $\mathrm{m} / \mathrm{z}=238$ was selected in the Q1 and $\mathrm{m} / \mathrm{z}=238$ and 254 in the Q2, respectively; for $\mathrm{UH}+, \mathrm{m} / \mathrm{z}=239$ was selected in both $\mathrm{Q} 1$ and $\mathrm{Q} 2$.

$220 \times 168 \mathrm{~mm}(300 \times 300 \mathrm{DPI})$ 


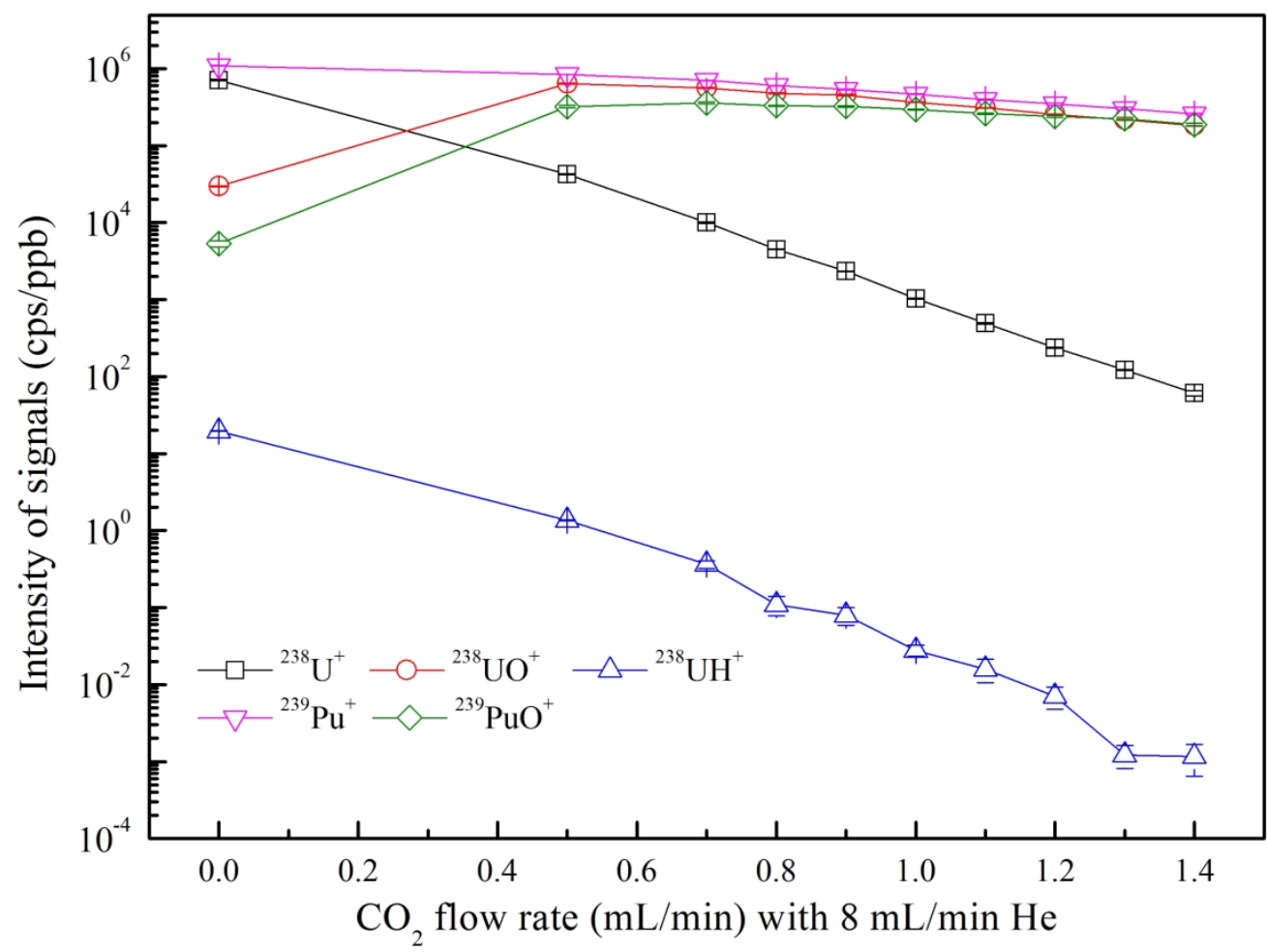

Figure 2 Variation of the intensities of $\mathrm{U}_{+}, \mathrm{UH}+, \mathrm{UO}+, \mathrm{Pu}+$ and $\mathrm{PuO}+$ ions with the flow rate of $\mathrm{CO} 2$ with 8 $\mathrm{ml} / \mathrm{min}$ helium injected to the DCR. For $\mathrm{U}+$ and $\mathrm{UO}+$ ions, $\mathrm{m} / \mathrm{z}=238$ was selected in $\mathrm{Q} 1$ (the first quadrupole) and $\mathrm{m} / \mathrm{z}=238$ and 254 in the $\mathrm{Q} 2$ (second quadrupole), respectively; For $\mathrm{UH}+$, Pu+ and PuO+, $\mathrm{m} / \mathrm{z}=239$ was selected in $\mathrm{Q} 1$ and $\mathrm{m} / \mathrm{z}=239,239$, and 255 , respectively. 239Pu standard solution of 2.0 $\mathrm{pg} / \mathrm{ml}$ and Uranium standard solution of $20 \mathrm{ng} / \mathrm{mL}$ and $1000 \mathrm{ng} / \mathrm{mL}$ (for $\mathrm{UH}+/ \mathrm{UH}+$ ) were used in this measurement.

$221 \times 165 \mathrm{~mm}(300 \times 300 \mathrm{DPI})$ 


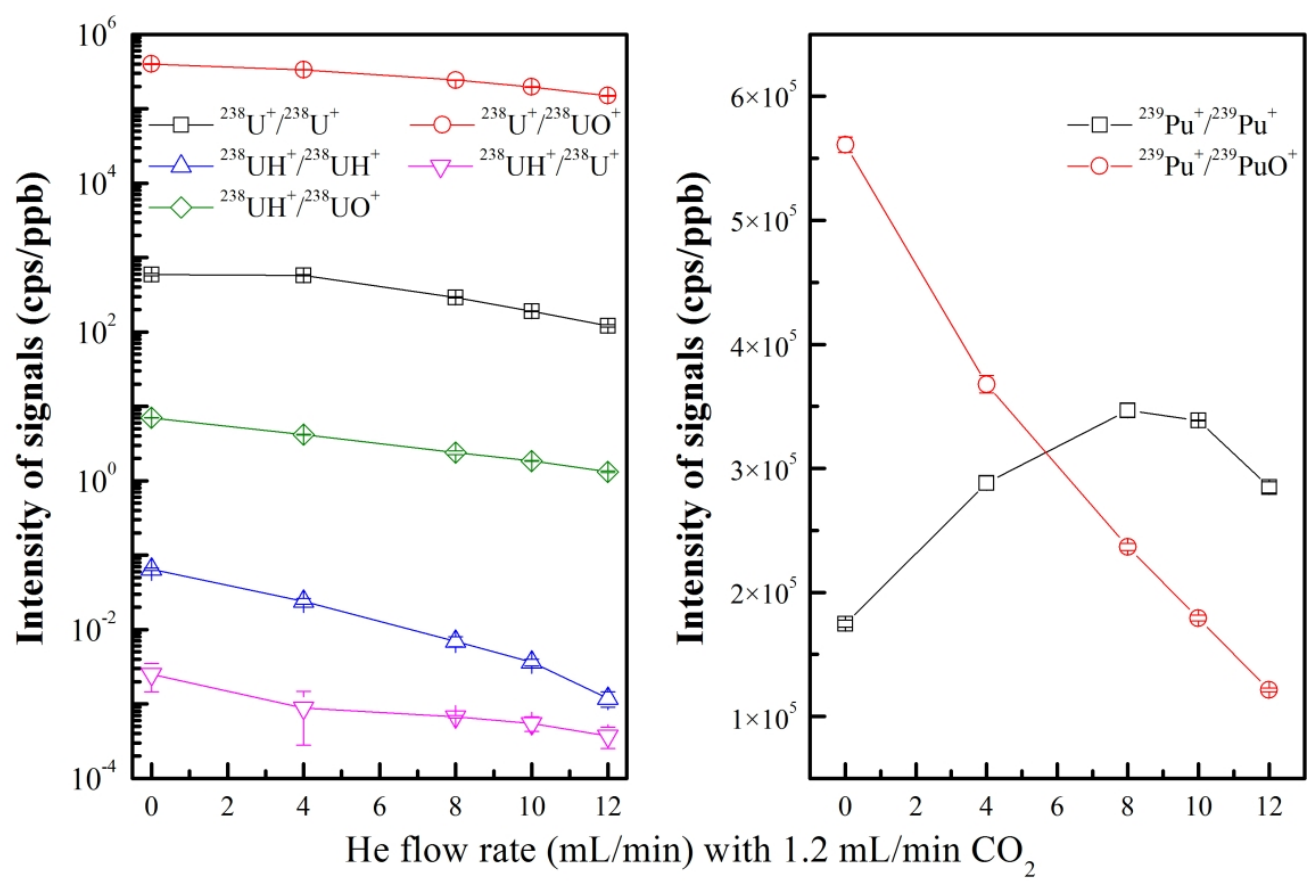

Figure 3 Influence of flow rate of helium injected to the DRC with $1.2 \mathrm{ml} / \mathrm{min} \mathrm{CO} 2$ on the intensities of the $\mathrm{Pu}+, \mathrm{PuO}+, \mathrm{U}+, \mathrm{UH}+$ and $\mathrm{UO}+$ ions. $238 \mathrm{UH}+/ 238 \mathrm{UO}+$ in the legend means that $\mathrm{m} / \mathrm{z}=239(238 \mathrm{UH}+)$ was selected for the first Quadrupole (Q1) and $\mathrm{m} / \mathrm{z}=255(238 \mathrm{U} 160+)$ was selected in the second quadrupole (Q2) mass separator, others are the similar meaning. The left figure is the measurement of a uranium standard solution, and the right figure is the measurement of a 239Pu standard solution. Note: the uncertainties presented in some data points are too small to be clearly visible.

$$
264 \times 178 \mathrm{~mm} \text { ( } 300 \times 300 \text { DPI) }
$$

